\title{
Public expenditure on health care in Orissa: Focus on reproductive and child health services
}

Sarit Kumar Rout

Follow this and additional works at: https://knowledgecommons.popcouncil.org/departments_sbsr-rh

Part of the Demography, Population, and Ecology Commons, Family, Life Course, and Society Commons, International Public Health Commons, Maternal and Child Health Commons, and the Public Health Education and Promotion Commons How does access to this work benefit you? Let us know!

\section{Recommended Citation}

Kumar Rout, Sarit. 2010. "Public expenditure on health care in Orissa: Focus on reproductive and child health services," Health and Population Innovation Fellowship Program Working Paper no. 12. New Delhi: Population Council. 


\section{Public Expenditure on Health Care in Orissa}

FOCUS ON REPRODUCTIVE AND CHILD HEALTH SERVICES

Sarit Kumar Rout

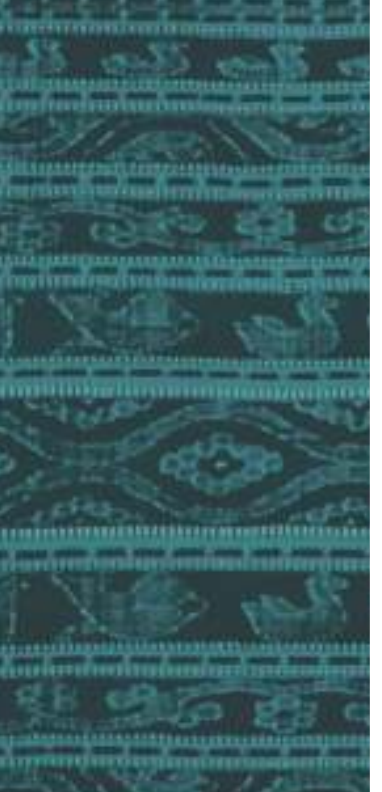

Sarit Kumar Rout 
This report is the result of a project entitled "Public Expenditure on Health Care in Orissa: Focus on Reproductive and Child Health Services" undertaken as part of the Health and Population Innovation Fellowship (HPIF) awarded to the author in 2006.

The HPIF programme is administered by the Population Council, New Delhi and is a continuation of the MacArthur Foundation's Fund for Leadership Development (FLD) fellowship programme that continued over the period 1995 to 2004. The Council is grateful to the MacArthur Foundation for its support to this programme.

The HPIF programme aims to support mid-career individuals who have innovative ideas, leadership potential, and the capacity to help shape policy and public debate in the field of population, reproductive health and rights in general, with a focus on two priority themes - maternal mortality and morbidity, and the sexual and reproductive health and rights of young people. Since the transfer of the programme to the Population Council through 2006, a total of 17 individuals have been supported under the HPIF programme.

For additional copies of this report, please contact:

Sarit Kumar Rout

C-48, Shubham Apartmentt

37 I.P. Extension

Patparganj

Delhi-110092

Email: saritrout@rediffmail.com
Population Council

Zone 5A, Ground Floor

India Habitat Centre

Lodi Road, New Delhi 110003

Phone: 011-24642901/02

Email: info-india@popcouncil.org

Web site: http://www.popcouncil.org/asia/india.html

The Population Council is an international, non-profit, non-governmental organisation that seeks to improve the well-being and reproductive health of current and future generations around the world and to help achieve a humane, equitable and sustainable balance between people and resources. The Council conducts biomedical, social science and public health research, and helps build research capacities in developing countries.

\section{Copyright (C) 2010 Sarit Kumar Rout}

About the author: Sarit Kumar Rout has been working as a policy analyst focusing on health and education for last 8 years. His major research areas include financing human development, health system development, public-private partnership in health care and national health accounts. Presently he is working as a National consultant health care financing with the Ministry of Health and Family Welfare, GOI and involved in developing the national Health Account for India. After obtaining M.PhIl in Applied and Analytical Economics, from Vanivihar, Utkal University, Bhubaneswar he is presently pursuing Ph.D in health economics from the Centre for Economic and Social Studies (CESS), Hyderabad.

Suggested citation: Sarit Kumar Rout. 2010. "Public Expenditure on Health Care in Orissa: Focus on Reproductive and Child Health Services", Health and Population Innovation Fellowship Programme Working Paper, No 12, New Delhi: Population Council. 


\section{Public Expenditure on Health Care in Orissa}

\section{FOCUS ON REPRODUCTIVE AND CHILD HEALTH SERVICES}

Sarit Kumar Rout

Fellow

Health and Population Innovation Fellowship Programme 


\section{Contents}

Introduction 1

Orissa: A profile 2

Methodology 5

Public Expenditure on Health Care 10

Total expenditure on health and health-related matters 10

Per capita health and health-related expenditure 13

Composition of health expenditure 16

Health expenditure by major heads 16

Health expenditure by sub-major heads 19

Health expenditure by minor heads 22

Health expenditure by plan and non-plan heads 22

Health expenditure by type of inputs 28

Health expenditure by type of health care function 31

Differences between budget estimates and actual expenditure 31

Public expenditure on reproductive and child health services 32

Conclusion 40

Acknowledgements 49

References 50 


\section{List of tables}

Table 1: Socio-economic and demographic profile of Orissa and India 3

Table 2: Major heads of expenditure on health 6

Table 3: Major heads of expenditure on health-related matters 7

Table 4: Major, Sub-major and Minor Heads of health Expenditure 8

Table 5: Public expenditure on health and health-related matters, Orissa, 1996-97 to 2007-08 (in Rs. crore) 11

Table 6: Share of health and health-related expenditure in total state expenditure and gross state domestic product, Orissa, 1996-97 to 2007-08 (percentage)

Table 7: Per capita health and health-related expenditure, Orissa, 1996-97 to 2007-08 (in Rs.)

Table 8: Average real per capita health and health-related expenditure, major states of India, 1991-92 to 2006-07 (in Rs.)

Table 9: Health expenditure by major heads, Orissa, 1996-97 to 2007-08 (in Rs. crore)

Table 10: Health expenditure by sub-major heads, Orissa, 1996-97 to 2007-08 (in Rs. crore) 20

Table 11: Health expenditure by minor heads, Orissa, 1996-97 to 2007-08 (in Rs. crore)

Table 12: Health expenditure by minor heads, Orissa, 1996-97 to 2007-08 (percentage)

Table 13: Plan and non-plan expenditure, Orissa, 1996-97 to 2007-08 (in Rs. crore)

Table 14: Health expenditure by type of inputs, Orissa, 1996-97 to 2007-08 (in Rs. crore)

Table 15: Health expenditure by health care function, Orissa, 2002-03 to 2007-08 (percentage)

Table 16: Difference between budget estimates and actual expenditure, Orissa, 2000-01 to 2006-07 (in Rs. crore)

Table 17: Public expenditure on reproductive and child health services, Orissa, 1996-97 to 2007-08 (in Rs. crore)

Table 18: Expenditure on reproductive and child health services by sources of funding, Orissa, 1996-97 to 2007-08 (percentage) 
Table 19: Composition of expenditure on reproductive and child health services, Orissa, 1996-97 to 2007-08 (in Rs. crore)

Table 20: RCH elements in the health and family welfare budget, Orissa, 1996-97 to 2007-08 (percentage) 38

\section{List of figures}

Figure 1: Share of health expenditure in total state expenditure and the state gross domestic product, Orissa, $1996-97$ to $2007-08$

Figure 2: Share of reproductive and child health expenditure in total health and health-related expenditure and gross state domestic product, Orissa, $1996-97$ to $2007-08$ 34

Figure 3: Expenditure on reproductive and child health services by sources of funding, Orissa, 1998-99 \& 2005-06 (percentage)

\section{List of appendices}

Appendix 1: Classification of health expenditure by health care functions 42

Appendix II: Calculation of expenditure on reproductive and child health services 44

\section{List of annexure tables}

Table 1.1 A: Major head wise classification of health-related expenditure, Orissa, 1996-97 to 2007-08 (in Rs crore) 45

Table 1.2 A: Sub-major head wise classification of health-related expenditure,

Orissa, 1996-97 to 2007-08, (in Rs crore) 46

Table 1.3 A: Plan and non-plan distribution of health-related expenditure, Orissa, 1996-97 to 2007-08 (in Rs. crore) 47

Table 1.4 A: Percentage of health expenditure (Medical and Public Health and Family Welfare) in total state expenditure of major states, 1990-91 to 2006-07 48 


\section{Acronyms}

$\begin{array}{lll}\text { AE } & - & \text { Actual Expenditure } \\ \text { BE } & - & \text { Budget Estimate } \\ \text { BPL } & - & \text { Below Poverty Line } \\ \text { CAGR } & - & \text { Compounded Annual Growth Rate } \\ \text { CHC } & - & \text { Community Health Centre } \\ \text { DLHS } & - & \text { District Level Household and Facility Survey } \\ \text { EAP } & - & \text { Externally Aided Project } \\ \text { FW } & - & \text { Family Welfare } \\ \text { GOI } & - & \text { Government of India } \\ \text { GOO } & - & \text { Government of Orissa } \\ \text { GSDP } & - & \text { Gross State Domestic Product } \\ \text { HUD } & - & \text { Housing and Urban Development } \\ \text { IMR } & - & \text { Infant Mortality Rate } \\ \text { IPD } & - & \text { Integrated Population and Development } \\ \text { MCH } & - & \text { Maternal and Child Health } \\ \text { MDG } & - & \text { Millennium Development Goal } \\ \text { NFHS } & - & \text { National Family Health Survey } \\ \text { NRHM } & - & \text { National Rural Health Mission } \\ \text { NSDP } & - & \text { Net State Domestic Product } \\ \text { OMDSS } & - & \text { Orissa Multi Disease Surveillance System } \\ \text { PH } & - & \text { Public Health } \\ \text { PHC } & - & \text { Primary Health Centre } \\ \text { RBI } & - & \text { Reserve Bank of India } \\ \text { RD } & - & \text { Rural Development } \\ \text { RCH } & - & \text { Reproductive and Child Health } \\ \text { RE } & - & \text { Revised Estimate } \\ \text { SRS } & - & \text { Sample Registration System } \\ & & \end{array}$




\section{Introduction}

The health situation in any country is influenced by both supply-side and demand-side factors. The key variables on the supply side are budgetary allocations, governance structure and policy decisions. The nature and pattern of financing not only determine the effectiveness of service delivery but also define the boundaries and capability of the system to achieve the objectives articulated in government policy documents.

Although health care expenditure is a key determinant of health outcomes, its analysis is fraught with constraints. One of the major constraints is the lack of consensus on what health care expenditure constitutes. Universally acceptable resolutions of this debate is difficult for both ideological reasons (health is recognized as being affected by much more than health care, but where one should draw the line is less well recognised) and practical ones (expenditure are combined in specific ways in each country and are often not easily disaggregated) (Berman, 1996). While some researchers argue that it should include all expenditures that primarily and significantly contribute towards improving the health status of people, and any other expenditure should be judged on its merit, others have used a broad definition that includes expenditure on medical and public health, family welfare, water supply and sanitation as well as that incurred not only by the Health and Family Welfare Department but also by Departments of Rural Development, and Women and Child Development (for example, Reddy and Selvaraju, 1994; Indira and Vyasulu, 2001). Yet other researchers have used a narrow definition that includes only expenditure incurred on medical and public health, and family welfare and excludes expenditure on water supply, sanitation and nutrition (for example, Rao, Khan and Prasad, 1987). Moreover, the fact that health care expenditure is sourced by a number of factors, namely, in the public sector, government and its agencies at the central, state and local level; private sector organisations and institutions including corporations and not-for-profit organisations; and individuals and households (Berman, 1991), complicates the process of making a comprehensive analysis of health care spending. This is further complicated by the lack of an appropriate accounting system in the private sector.

In view of the importance of public financing in influencing health outcomes and the paucity of studies that have explored patterns of resource allocation on reproductive and child health services, a study was undertaken, to examine the pattern of and trends in public expenditure on health care in Orissa, with a special focus on expenditure on reproductive and child health services. The study covered a 12-year period-from 1996-97 to $2007-08$. 


\section{Orissa: A profile}

Orissa, located in the eastern region of India, is India's ninth largest state in terms of area. Its population of 37 million (Office of the Registrar General and Census Commissioner, 2001) makes it the eleventh most populous state of India. Its sex ratio of 972 females per 1,000 males is higher than the national average of 933 females per 1,000 males. Scheduled tribes and scheduled castes constitute substantial proportions of Orissa's total population-22 percent and 17 percent, respectively.

Economically, Orissa is one of the least developed states in the country. Its per capita income at constant prices (1999) stood at Rs. 13,748 in 2005-06, well below the national average of Rs. 20,734. Poverty levels remain high in 2004-2005, almost two-fifths (40 percent) of the population was estimated (using the mixed recall period method) to be below the poverty line, the highest among all the states. The primary sector continues to be the mainstay of the economy and contributed 40 percent of the net state domestic product in 2005-06; about 70 percent of the workforce was engaged in agricultural activities either directly or indirectly.

The state lags behind other states in terms of social indicators as well. For example, the overall literacy rate was slightly lower than the national average in 2001 (63 percent versus 65 percent), and the female literacy rate was 51 percent (compared to the national average of 54 percent).

The state's performance in the health sector has also been poor. Life expectancy for males and females is lower than the national average during 2002-06 (60 versus 62 years for males and 60 versus 64 years for females) (RGI, 2009a). Besides, the infant mortality rate of 69 is the second highest among the country's major states. Further, 65 percent of children under 5 years of age were anaemic, 41 percent were underweight and a little over half of those aged 12-23 month were fully immunized (compared to 70 percent, 43 percent and 44 percent, respectively, nationally). The fertility rate, however, was slightly lower than the national average (2.4 versus 2.7 ). With regard to maternal health, Orissa's maternal mortality ratio of 303 per 100,000 live births places it sixth highest among the states of India; only 36 percent of the childbirths in the state took place in a health facility and less than half (44 percent) were attended by a health care professional.

In terms of health infrastructure, data emphasise the large gap between infrastructural requirements and availability In 2006, there were 1,701 medical institutions including PHCs, CHCs, and sub-divisional and district hospitals, serving, on average, a population of 23,329 per institution compared to 1,520 medical institutions in 1991, serving on average, a population of 20,829 per institution (data derived from the figures given in the Economic Survey of various years, Government of Orissa). The short supply of health facilities is reflected by the disturbing bed-population ratio: 1:2830 in 2006 against 1:2462 in 1991 (data derived from the figures given in the Economic Survey of various years, Government of Orissa), indicating that the bed strength had not increased to cater to the growing population. 
Table 1:

Socio-economic and demographic profile of Orissa and India

\begin{tabular}{|c|c|c|}
\hline Indicators & Orissa & India \\
\hline Total population ${ }^{1}$ (in millions) & 36.8 & 1028.6 \\
\hline Decadal growth ${ }^{1}(\%)$ & 16.3 & 21.5 \\
\hline Sex ratio $^{1}$ & 972 & 933 \\
\hline Schedule caste population ${ }^{1}(\%)$ & 16.5 & 16.2 \\
\hline Schedule tribe population ${ }^{1}(\%)$ & 22.1 & 8.2 \\
\hline Female literacy rate ${ }^{1}(\%)$ & 50.5 & 53.7 \\
\hline Per capita NSDP in $2005-06^{2}$ (in Rs. at $1999-2000$ prices) & 13,748 & 20,734 \\
\hline $\begin{array}{l}\text { Population below the poverty line }{ }^{2}(\%)(2004-2005 \text {, using } \\
\text { the mixed recall period method) }\end{array}$ & 39.9 & 21.8 \\
\hline Infant mortality rate ${ }^{3}$ (SRS, 2008) & 69 & 53 \\
\hline Maternal mortality ratio ${ }^{4}$ (SRS, 2004-2006) & 303 & 254 \\
\hline Total fertility rate $(\mathrm{TFR})^{5}$ & 2.4 & 2.7 \\
\hline Children aged 6-59 months who are anaemic ${ }^{5}(\%)$ & 65.0 & 69.5 \\
\hline Children under age five years who are underweight ${ }^{5}(\%)$ & 40.7 & 42.5 \\
\hline Children aged $12-23$ months fully immunised ${ }^{5}$ & 51.8 & 43.5 \\
\hline Institutional delivery, births during last five years ${ }^{5}(\%)$ & 35.6 & 38.7 \\
\hline $\begin{array}{l}\text { Births during last five years attended by Doctor/Nurse/ANM/ } \\
\text { LHV/other health personnel }{ }^{5}(\%)\end{array}$ & 44.0 & 46.6 \\
\hline
\end{tabular}

Sources: ${ }^{1}$ Office of the Registrar General and Census Commissioner. 2001. Primary Census Abstract, Total Population: Table A-5, Series 1. New Delhi: Office of the Registrar General and Census Commissioner.

${ }^{2}$ Directorate of Economics and Statistics. 2005-06 to 2008-09. Economic Survey, Planning and Coordination Department, Government of Orissa.

${ }^{3}$ Office of Registrar General, India. 2009a. SRS Bulletin: Sample Registration System, 44(1).

New Delhi: RGI.

${ }^{4}$ Office of Registrar General, India. 2009b. Special Bulletin on Maternal Mortality in India 2004-06. New Delhi: RGI.

${ }^{5}$ International Institute for Population Sciences (IIPS) and Macro International. 2008. National Family Health Survey (NFHS-3), India, 2005-06. Mumbai: IIPS.

The utilisation of public health facilities for out-patient care has grown from 37 percent in rural and 43 percent in urban areas to 51 and 54 percent, respectively (NSSO, 2006). A little over half of both urban and rural out-patients in Orissa utilise medical services from public health care institutions. This is against 22 and 19 percent utilisation of public sector health services in rural and urban India, respectively (NSSO, 2006). These findings point to the greater dependence of the population on public health facilities in Orissa, a state characterised by widespread poverty and deprivation, than in India more generally. However, evidence has pointed to huge infrastructural gaps in public health care institutions, and suggests that they do not operate at optimal levels: For example, the DLHS-3 reveals that only 60 percent of sub-centres operate in government buildings, only 43 percent of ANMs reside at the sub-centre level, only 49 percent of Primary Health Centres have 4 or more beds, and only 54 percent of CHCs are designated as first referral units (FRU) (IIPS, 2007-08). The situation is even worse in tribal and remote areas of the state. 
In this context, it is important to discuss out-of-pocket expenditure and whether the state government is able to protect Orissa's large number of poor families from health shocks. As revealed elsewhere (see, for example, MOHFW, 2005; 2009), out-of pocket-expenditure represented 77 percent of total health expenditure in 2001-02, and slightly more, 80 percent, in 2004-05. This huge percentage of out-of-pocket expenses - even in the decade of the 2000 s - highlights the inadequate availability of public services and the huge burden placed on the poor in accessing medical services.

The state government has articulated its commitment to improve the health situation in several policy and programme documents. For example, the Orissa State Integrated Health Policy enunciated in 2002 (Health and Family Welfare Department, Government of Orissa, 2002), aims to improve the health status of the people by providing health care in a socially equitable, accessible and affordable manner within a reasonable timeframe. Specifically, it proposes to reduce the maternal mortality ratio to 100 per 100,000 live births and the infant mortality rate to 45 per 1,000 births; eradicate polio, yaws and leprosy; reduce mortality due to malaria and other vector- and water-borne diseases by 50 percent; increase utilisation of public health facilities to over 75 percent; establish effective partnerships between public, private and voluntary sectors at local, district and state levels; and create adequate infrastructure in the public health system. The policy espouses a participatory approach that seeks involvement of communities and stakeholders in decision-making, planning and implementation of health programmes. Similar commitments have been articulated in the Orissa Vision 2010 document (Health and Family Welfare Department, Government of Orissa, 2003).

Apart from implementing specific, centrally-sponsored programmes, the state government has launched a number of special programmes to achieve some of the goals articulated in the 2002 Health Policy and Orissa Vision 2010 documents. For example, an infant mortality reduction mission, launched in 2001, aims at reducing infant mortality to 60 by 2005 ; while the Navajyoti scheme introduced in 2005 proposes to reduce neonatal mortality and morbidity, with a special focus on 14 districts in which the infant mortality rate exceeded the state average. Similarly, since 2001, the Pancha Byadhi Chikitsa scheme guarantees free treatment and medicines for the five common communicable diseases-malaria, leprosy, diarrhoea, acute respiratory infection and scabies.

With regard to health care financing in the state, the Orissa State Integrated Health Policy proposes that public expenditure on health care is to the tune of 2 percent of the gross state domestic product (GSDP) and 5-6 percent of the state budget. It also proposes to allocate 55 percent of public health care spending for primary care, 35 percent for secondary care and 10 percent for tertiary care besides advocating equitable distribution of resources between rural and urban areas, worse-off and better-off districts, and allopathic and Indian systems of medicine. Moreover, a number of initiatives have been introduced. For example, in 1991, the government introduced user fees in tertiary care hospitals for three categories of services namely, diagnostics, special accommodation and transportation. While those living below the poverty line were exempted from user fees, the income collected from others was retained by the district health societies and used for improving facilities at district level hospitals. In 1998, the government formed a State Health Family Welfare Society to channelize off-budget funds and improve efficiency in the allocation and utilisation of such funds. In 1999, a district level Zilla Swasthya Samiti was established, by amalgamating existing societies dealing with various centrally and donor-sponsored programmes, to serve as a nodal agency for health and family welfare activities in the district.

4 Sarit Kumar Rout 


\section{Methodology}

Data presented in this paper were drawn from various budget documents of the state government such as Demand for Grants, Budget at a Glance, Annual Financial Statements, and Finance Accounts as well as publications of the Reserve Bank of India. The analysis used budget expenditure across a 12-year period, from 1996-97 to 2007-08 (including estimated budget expenditure for 2006-07 and 2007-08). The classification of budget heads as mentioned in the Finance Accounts certified by the Comptroller and Auditor General of India was adopted for grouping budget heads (Comptroller and Auditor General of India, 2006).

Two major types of expenditure have been considered for analysing public expenditure on health care namely, expenditure on health and expenditure on health-related matters.

Expenditure on health includes (a) expenditure incurred by the Health and Family Welfare Department; (b) expenditure incurred on health by Departments of Labour and Employment, Rural Development, Housing and Urban Development, and Public Works; and (c) expenditure routed outside the state budget comprising allocations for specific projects by the central government and donor agencies. Table 2 describes the major expenditure heads pertaining to health in these government departments. Specifically, expenditure on health incurred by the Health and Family Welfare Department has been classified under six major expenditure heads-Medical and Public Health (2210); Family Welfare (2211); Secretariat and Social Services (2251); Aid, Material and Equipments (3606); Capital Outlay on Medical and Public Health (4210); and Capital Outlay on Housing (4216). Of these, the first four items relate to revenue expenditure and the last two to capital expenditure.

Expenditure under the 'Medical and Public Health' head includes expenditure on various health care facilities, including sub-centres, $\mathrm{PHCs}, \mathrm{CHCs}$, district and sub-divisional hospitals; medical colleges and hospitals; and for prevention and control of diseases, promotion of other systems of medicine, and national malaria and filaria control programmes. The expenditure incurred under the 'Medical and Public Health' head is largely sourced from the state government's own resources. On the other hand, a major chunk of resources under the 'Family Welfare' head comes from the central government and covers expenditure incurred on family welfare programmes including, postpartum centres, rural family welfare and urban family welfare centres, sub-centres, reproductive and child health services, training of nurse-midwives, expenditure on state institutes of health and family welfare and other activities related to improving maternal and child health. Expenditure incurred under the 'Medical and Public Health' head by the Departments of Labour and Employment, Rural Development, and Public Works as well as that incurred under capital expenditure under the 'Medical and Public Health' head by the Departments of Rural Development, Housing and Urban Development, and Public Works were summed to calculate the total health expenditure of other departments. Finally, funds that are not routed through the state budget, but made available to the state for centrally sponsored programmes like the National Rural Health Mission (NRHM) and certain externally aided projects financed by bilateral and multilateral agencies were also included for calculating the expenditure on health. 
Table 2:

Major heads of expenditure on health

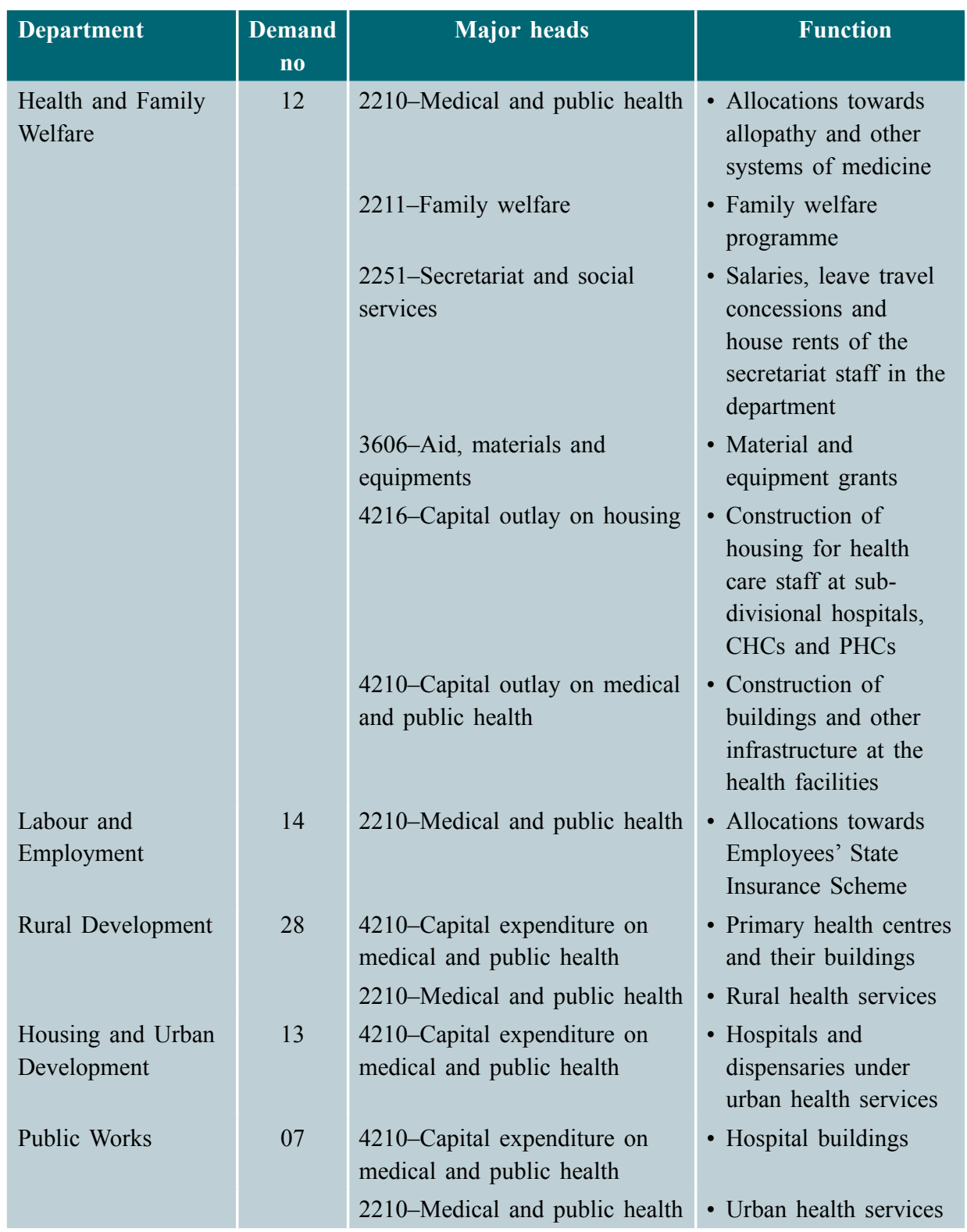

Source: Finance Department, Government of Orissa. 2007. Explanatory Memorandum (Budget 2007-2008). Government of Orissa. 
Health-related expenditure includes (a) expenditure on water supply and sanitation incurred by the Department of Housing and Urban Development and Department of Rural Development; and (b) expenditure on nutrition incurred by the Department of Women and Child Development. Table 3 describes the major expenditure heads pertaining to health-related matters in these departments.

Table 3:

Major heads of expenditure on health-related matters

\begin{tabular}{|c|c|c|c|}
\hline Department & $\begin{array}{c}\text { Demand } \\
\text { no }\end{array}$ & Major head & Function \\
\hline $\begin{array}{l}\text { Housing and Urban } \\
\text { Development }\end{array}$ & 13 & $\begin{array}{l}\text { 2215-Water supply and } \\
\text { sanitation } \\
4215-\text { Capital outlay on water } \\
\text { supply and sanitation }\end{array}$ & $\begin{array}{l}\text { - Water supply and } \\
\text { sanitation }\end{array}$ \\
\hline Rural Development & 28 & $\begin{array}{l}\text { 2215-Water supply and } \\
\text { sanitation } \\
4215 \text {-Capital outlay on water } \\
\text { supply and sanitation }\end{array}$ & $\begin{array}{l}\text { - Water supply and } \\
\text { sanitation }\end{array}$ \\
\hline $\begin{array}{l}\text { Women and Child } \\
\text { Development }\end{array}$ & 36 & 2236-Nutrition & - Nutrition \\
\hline
\end{tabular}

Source: Finance Department, Government of Orissa. 2007. Explanatory Memorandum (Budget 2007-2008). Government of Orissa.

Table 4 explains the classification of health expenditure into major heads (with four digits), sub-major heads (with two digits) and minor heads (with three digits). This classification is followed by both the central and state governments. As seen from the table, each major head of expenditure has its corresponding sub-major and minor heads; thus, expenditure on the 'Medical and Public Health' head (2210) is further distributed among seven sub-major heads and sixteen minor heads, while the 'Family Welfare' head (2211) does not have any sub-major heads but has nine minor heads. Likewise, the major heads of 'Secretariat and Social Services' (2251) and 'Aid, Materials and Equipments' (3606) do not have sub-major heads.

The study attempts to present a comprehensive picture of public spending on health care in Orissa during the period 1996-97 to 2007-08. Thus, in addition to examining the total and per capita health and health-related expenditure, it seeks to explore the disaggregated pattern of health spending by including components of health expenditure incurred not only by the Health and Family Welfare Department but by other departments (see Table 2) as well. Likewise, it includes spending on health-related programmes such as water supply, sanitation and nutrition (see Table 3) which contribute to the promotion of health among the people. Finally, it includes expenditure routed through societies which are not part of the state budget. It may be noted though that it does not include out-of-pocket expenditure incurred by individual households or the money spent by NGOs, corporate houses and urban and rural local bodies. In other words, the findings presented in this report pertain only to government expenditure on health care. 
Table 4:

Major, Sub-major and Minor Heads of health Expenditure

\begin{tabular}{|c|c|c|}
\hline Major head & Sub major heads & Minor heads \\
\hline \multirow[t]{7}{*}{$\begin{array}{l}\text { 2210-Medical and } \\
\text { Public Health }\end{array}$} & $\begin{array}{l}\text { 01-Urban health } \\
\text { services-Allopathy }\end{array}$ & $\begin{array}{l}\text { 001-Direction and Administration } \\
\text { 110-Hospitals and Dispensaries } \\
\text { 200-Other Health Schemes } \\
\text { 800-Other Expenditure }\end{array}$ \\
\hline & $\begin{array}{l}02-\text { Urban health } \\
\text { services-Other systems } \\
\text { of medicine }\end{array}$ & $\begin{array}{l}\text { 001-Direction and Administration } \\
\text { 101-Ayurveda } \\
\text { 102-Homeopathy } \\
\text { 103-Unani }\end{array}$ \\
\hline & $\begin{array}{l}\text { 03-Rural health } \\
\text { services-Allopathy }\end{array}$ & $\begin{array}{l}\text { 103-Primary Health Centres } \\
\text { 104-Community Health Centres } \\
\text { 110-Hospitals and dispensaries } \\
\text { 796-Tribal Areas Sub plan } \\
\text { 800-Other Expenditure }\end{array}$ \\
\hline & $\begin{array}{l}04-\text { Rural health } \\
\text { services-Other systems } \\
\text { of medicine }\end{array}$ & $\begin{array}{l}\text { 101-Ayurveda } \\
\text { 102-Homeopathy } \\
\text { 103-Unani } \\
\text { 796-Tribal Areas Sub plan }\end{array}$ \\
\hline & $\begin{array}{l}\text { 05-Medical education. } \\
\text { training and research }\end{array}$ & $\begin{array}{l}\text { 101-Ayurveda } \\
\text { 102-Homeopathy } \\
\text { 105-Allopathy }\end{array}$ \\
\hline & 06-Public health & $\begin{array}{l}\text { 101-Prevention and Control of } \\
\text { Diseases } \\
\text { 001-Direction and Administration } \\
\text { 104-Drug Control } \\
\text { 107-Public Health Lboratories } \\
\text { 113-Public Health and Publicity } \\
\text { 796-Tribal Areas Sub plan } \\
\text { 800-Other Expenditure }\end{array}$ \\
\hline & 80-General & 004-Health Statistics and Evaluation \\
\hline 2211-Family Welfare & No sub-major head & $\begin{array}{l}\text { 001-Direction and Administration } \\
003-\text { Training } \\
\text { 101-Rural Family Welfare Services } \\
\text { 102-Urban Family Welfare Services } \\
\text { 103-Maternal and Child Health } \\
\text { 104-Transport } \\
\text { 105-Compensation } \\
\text { 200-Other Services and Supplies } \\
\text { 796-Tribal Areas Sub plan }\end{array}$ \\
\hline
\end{tabular}

Cont'd on next page...

8 Sarit Kumar Rout 
Table 4: (Cont'd)

\begin{tabular}{l|l|l|}
\hline Major head & \multicolumn{1}{|c|}{ Sub major heads } & \multicolumn{1}{c|}{ Minor heads } \\
\hline $\begin{array}{l}\text { 2251-Secretariat and } \\
\text { Social Services }\end{array}$ & No sub major head & 090 -Secretariat and Social Services \\
\hline $\begin{array}{l}\text { 3606-Aid, Materials } \\
\text { and Equipments }\end{array}$ & No sub major head & $\begin{array}{l}103-\text { Trachoma of Blindness Control } \\
104-\text { National Malaria Eradication } \\
\text { Programme }\end{array}$ \\
\hline $\begin{array}{l}\text { 4210-Capital Outlay } \\
\text { on Medical and } \\
\text { Public Health }\end{array}$ & $\begin{array}{l}\text { 01-Urban health } \\
\text { services }\end{array}$ & $\begin{array}{l}110-\text { Hospitals and Dispensaries } \\
796-\text { Tribal areas Sub plan } \\
800-\text { Other Expenditure }\end{array}$ \\
\hline $\begin{array}{l}\text { 4216-Capital Outlay } \\
\text { on Housing }\end{array}$ & $\begin{array}{l}01-\text {-Government } \\
\text { residential buildings }\end{array}$ & $\begin{array}{l}796-\text { Tribal Areas sub plan } \\
800-\text { Other Expenditure }\end{array}$ \\
\hline
\end{tabular}

Source: Finance Department, Government of Orissa. 2007. Explanatory Memorandum (Budget 2007-2008). Government of Orissa.

Different classification schemes were used for disaggregating health expenditure namely,

(a) major expenditure heads; (b) sub-major heads; (c) minor expenditure heads; and (d) plan and non-plan expenditure. Plan expenditure includes expenditure incurred on different programmes and schemes outlined in the five-year plans while non-plan expenditure includes all government expenditure which has been committed and includes expenditure on salaries, interest payment, office expenses and other day-to-day expenditure of the government.

The analysis also provides disaggregated information on the total health expenditure incurred by the Health and Family Welfare Department by type of inputs and type of health care function. The inputs explored include such items as salaries and wages; office expenses; medicine; diet; supplies such as bedding, clothing and linen; scholarship and so on. The type of health care functions explored includes primary, secondary and tertiary health care functions.

Finally, expenditure on reproductive and child health services, which the study seeks to examine specially, was calculated by summing up the (a) expenditure incurred under the major head 'family welfare' by the Health and Family Welfare Department; (b) expenditure incurred on two sub-heads - the Institute of Paediatrics, Cuttack, and maternity and child welfare centres - under the major head, 'medical and public health' by the Health and Family Welfare Department; (c) expenditure incurred under the 'distribution of nutritious food and beverages' head (excluding expenditure on the mid-day meal scheme) by the Department of Women and Child Development; and (d) resources made available for supporting such programmes as RCH-II, immunization and pulse polio programme under the NRHM. 


\section{Public Expenditure on Health Care}

This chapter describes the pattern of and trends in public expenditure on health care in Orissa. Specifically, it describes the magnitude of public expenditure on health and healthrelated aspects in general and on reproductive and child health services in particular.

\section{Total expenditure on health and health-related matters}

Table 5 presents the magnitude of public expenditure incurred by the state on health as well as health-related matters from 1996-97 to 2007-08. The data indicate that the total expenditure on health (incurred by the Health and Family Welfare Department as well as the other concerned departments and off-budget projects) increased steadily during the fiveyear period- from Rs. 294 crore in 1996-97 to Rs. 512 crore in 2000-01. The subsequent five-year period, 2001-02 to 2005-06, however, witnessed some fluctuations; for example, in 2001-02, the year in which the state experienced a major deterioration in its fiscal situation, it registered a slight decline as compared to the previous year; a similar decline was observed in 2005-06. It is important to mention here that there was a substantial mismatch between revenue receipts and expenditure leading to a rise in the revenue deficit of 6.54 percent of GSDP in 2001-02 (Finance Department, GOO, 2003-04). In 2007-08, the total expenditure on health stood at Rs. 842 crore.

Findings also indicate that the expenditure incurred by the Health and Family Welfare Department alone accounted for over 90 percent of the state's total health expenditure for a major part of the 12-year period under study, except in 2005-07 when it accounted for 70-78 percent. The expenditure incurred by other departments during this period remained more or less unchanged at just 2-5 percent of the total public spending on health. While contributions from externally-funded projects and central assistance routed outside the state budget accounted for 7 percent or less of public expenditure on health during 1996-97 to 2004-05, it accounted for as much as 20-28 percent during 2005-06. Health-related expenditure, namely, that on water supply, sanitation and nutrition, increased from Rs. 244 crore in 1996-97 to Rs. 614 crore in 2005-06 (actual), and was estimated at Rs. 819 crore in 2007-08 (BE).

Findings further indicate considerable fluctuations in the size of health-related expenditure during the 12-year period. Taken together, health and health-related expenditure increased from Rs. 538 crore in 1996-97 to Rs. 1,246 crore in 2005-06 (actuals), Accounts and was further estimated to rise to Rs. 1,628 crore in 2007-08 (BE).

Table 6 and Figure 1 present the expenditure on health expressed as a percentage of GSDP and of the total expenditure of the state. As a share of GSDP, health expenditure remained around 1 percent throughout the study period. However, as a percentage of total state spending, it declined in actual terms from 4.66 percent in 1996-97 to 3.98 percent in 2005-06. This decline was particularly evident after 2000-01 when the state government introduced a number of fiscal consolidation measures to arrest a fiscal crisis arising from a 


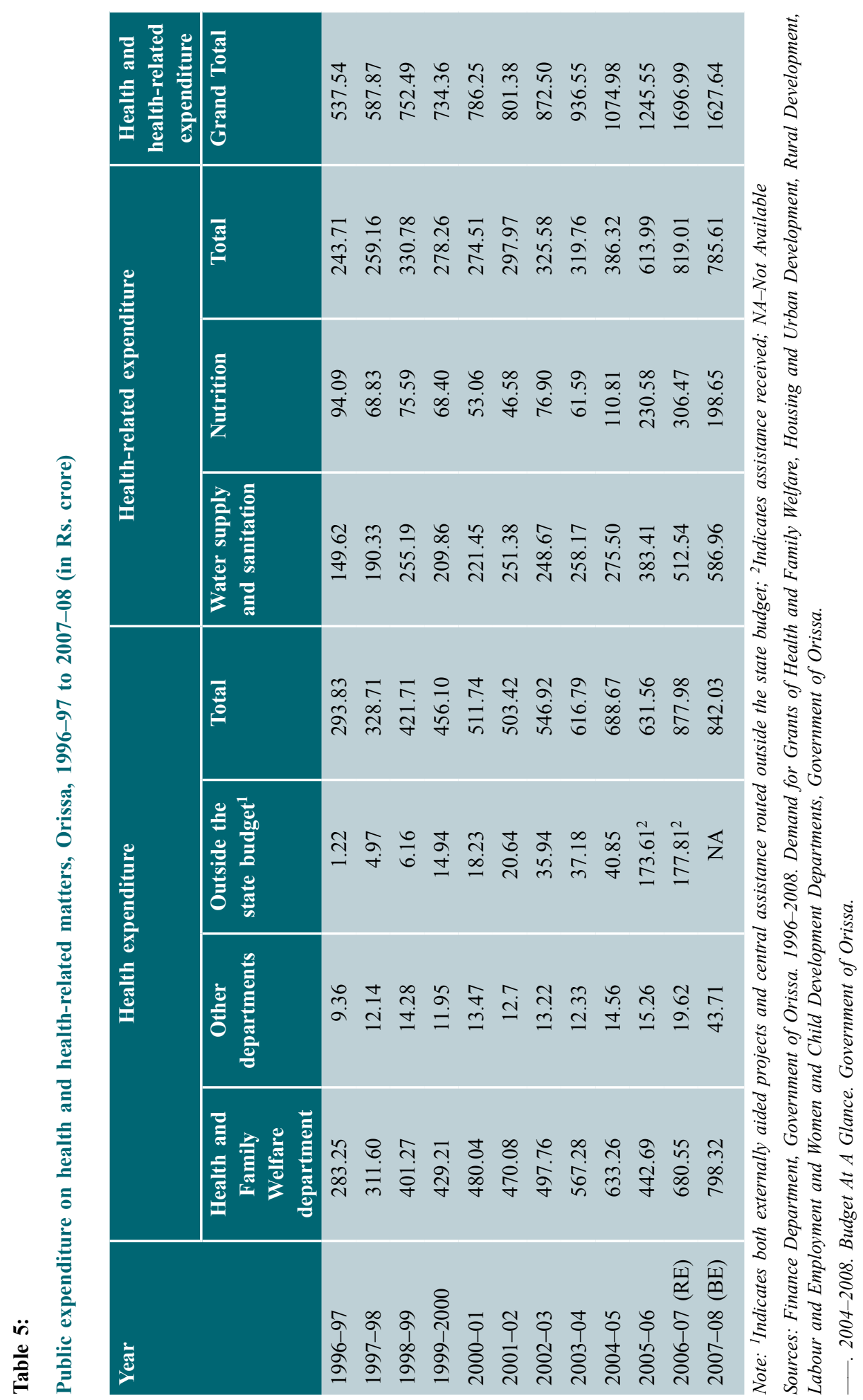

11 Public Expenditure on Health Care in Orissa: Focus on Reproductive and Child Health Services 


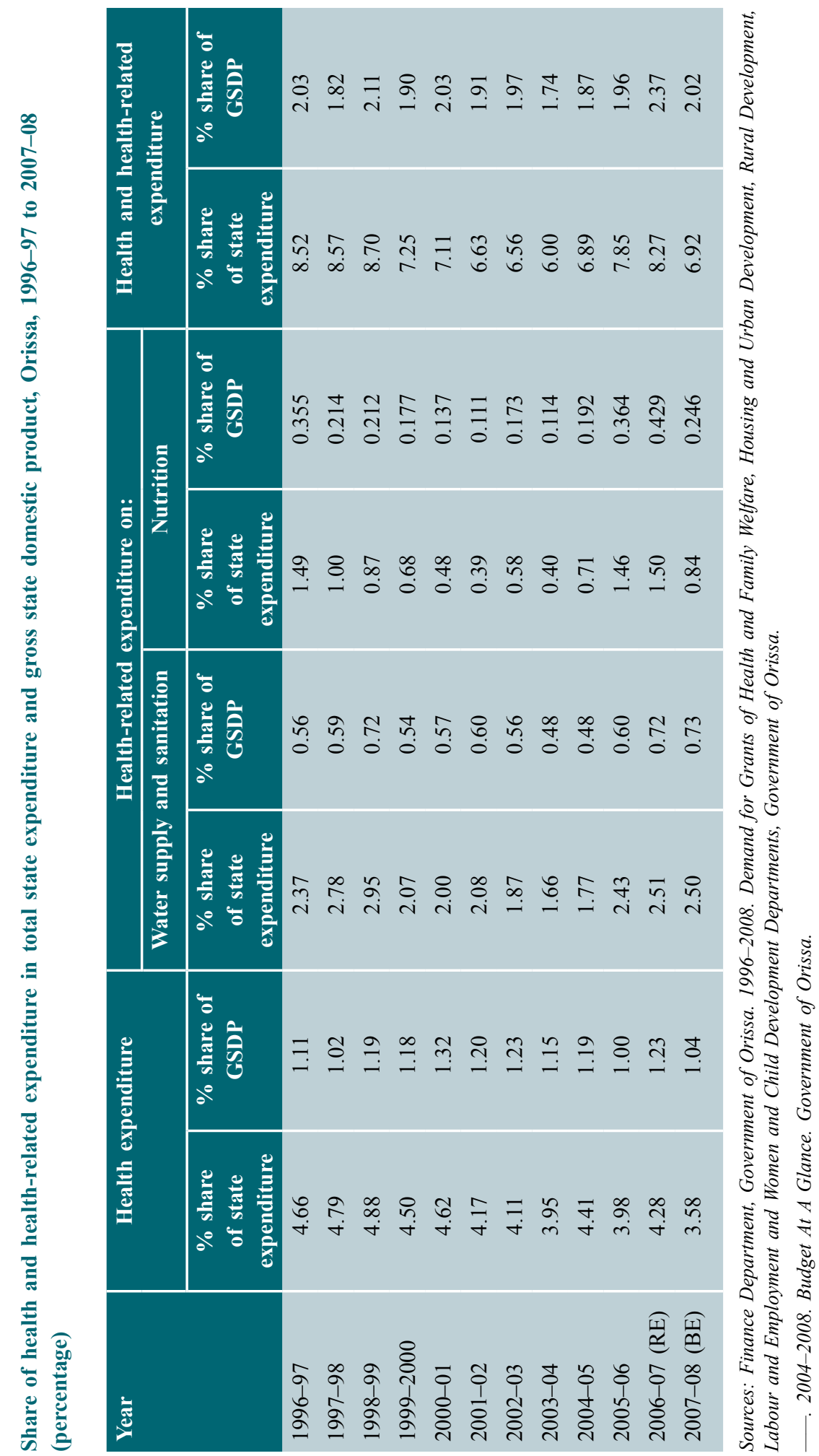

12 Sarit Kumar Rout 
mismatch between revenue receipts and revenue expenditure (particularly salaries, interest payments and other committed expenditure) which rose substantially above the receipts, resulting in a rise in public borrowing which reached 50.84 percent of GSDP in 2001-02 (Finance Department, GOO, 2007-08). This, in turn, led to a reduction in the resources allocated for health.

As regards health-related expenditure, its proportion was about 2 percent of GSDP during the study period but fluctuated as a share of state spending; increasing from 8.52 percent in 1996-97 to 8.70 percent in 1998-99; it declined thereafter to reach 6.89 percent in 2004-05. In 2005-06, it again increased marginally due to an increase in central funds under NRHM, and reached 8.27 percent in 2007-08 (revised estimate).

\section{Figure 1:}

Share of health expenditure in total state expenditure and the state gross domestic product, Orissa, 1996-97 to 2007-08

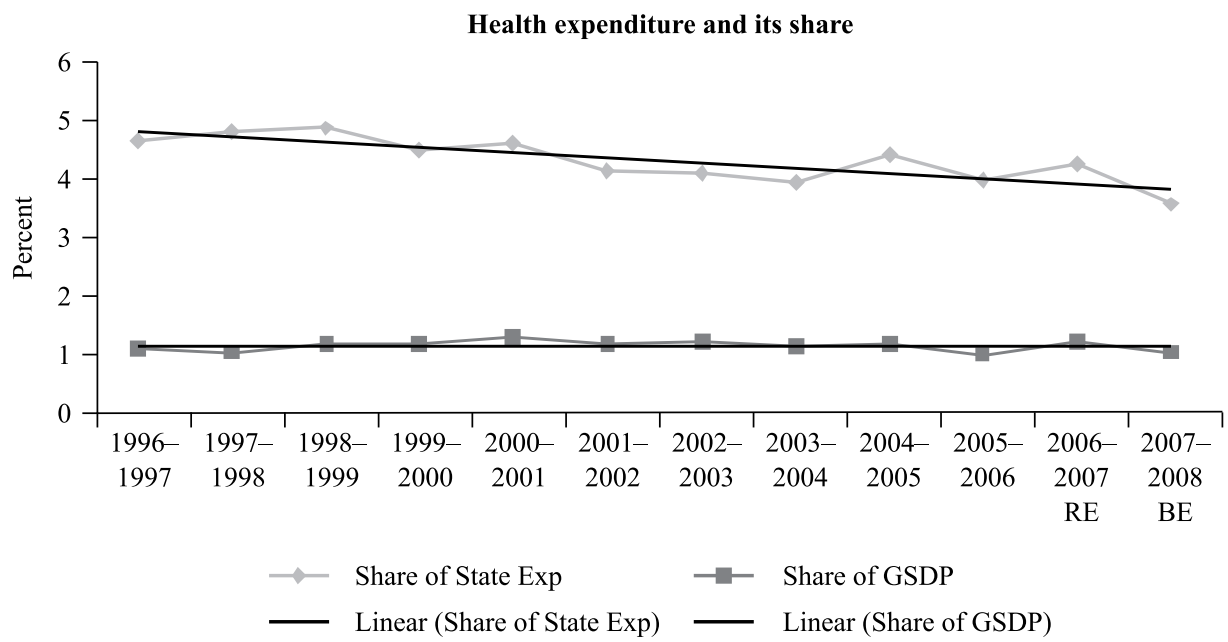

Sources: Finance Department, Government of Orissa. 1996-2008. Demand for Grants of Health and Family Welfare, Housing and Urban Development, Rural Development, Labour and Employment Departments, Government of Orissa.

- 2004-2008. Budget At A Glance. Government of Orissa.

\section{Per capita health and health-related expenditure}

Per capita health and health-related expenditure at current and constant prices during the period 1996-97 to 2007-08 is presented in Table 7. At current prices, the per capita health expenditure was Rs. 159 in 2005-06 and estimated to rise to Rs. 206 in 2007-08 (BE) while at constant prices, it grew from Rs. 67 to reach Rs. 95 in 2007-08. Thus, while at current prices, the per capita health expenditure grew by almost 8 percent during the period under study, the rate of growth at constant prices was merely 3 percent. 
Table 7: Per capita health and health-related expenditure, Orissa, 1996-97 to 2007-08 (in Rs.)

\begin{tabular}{|l|c|c|c|c}
\hline Year & $\begin{array}{c}\text { Per capita } \\
\text { health } \\
\text { expenditure at } \\
\text { current prices }\end{array}$ & $\begin{array}{c}\text { Per capita } \\
\text { health } \\
\text { expenditure } \\
\text { at constant } \\
\text { prices }^{1}\end{array}$ & $\begin{array}{c}\text { Per capita } \\
\text { health and } \\
\text { health-related } \\
\text { expenditure at } \\
\text { current prices }\end{array}$ & $\begin{array}{c}\text { Per capita } \\
\text { health and } \\
\text { health-related } \\
\text { expenditure } \\
\text { at constant } \\
\text { prices }^{1}\end{array}$ \\
\hline 1996-97 & 84.80 & 66.66 & 155.12 & 121.95 \\
$1997-98$ & 93.44 & 70.36 & 167.11 & 125.83 \\
$1998-99$ & 118.09 & 83.93 & 210.71 & 149.76 \\
$1999-2000$ & 125.81 & 86.58 & 202.56 & 139.41 \\
2000-01 & 139.04 & 89.30 & 213.63 & 137.20 \\
2001-02 & 134.85 & 83.60 & 214.59 & 133.04 \\
2002-03 & 144.17 & 86.44 & 230.01 & 137.90 \\
2003-04 & 160.18 & 91.07 & 243.23 & 138.28 \\
2004-05 & 176.18 & 94.06 & 275.00 & 146.83 \\
2005-06 & 159.15 & 81.38 & 313.88 & 160.51 \\
2006-07 (RE) & 217.94 & 105.69 & 421.25 & 204.28 \\
2007-08 (BE) & 205.90 & 94.69 & 398.00 & 183.03 \\
CAGR & 7.86 & 2.77 & 8.55 & 3.42 \\
Average & 146.63 & 86.15 & 253.76 & 148.17 \\
\hline
\end{tabular}

Note: ${ }^{1}$ WPI deflator 1999 was used to calculate the real per capita expenditure.

Sources: Finance Department, Government of Orissa. 1996-2008. Demand for Grants of Health and Family Welfare, Housing and Urban Development, Rural Development and Labour and Employment Departments, Government of Orissa.

—. 2004-2008. Budget At A Glance. Government of Orissa.

At current prices, the per capita health and health-related expenditure stood at Rs. 398 in 2007-08, showing a growth of 9 percent during the study period. At constant prices, it was only Rs. 183 in $2007-08$, indicating only a 3 percent rate of growth. The average per capita health and health-related expenditure was only Rs. 148 during this period.

Table 8 presents average real per capita health and health-related expenditure for the major states during the period 1990-91 to 2006-07. The data presented in the table cover only the expenditure incurred under the 'Medical and Public Health' and 'Family Welfare' heads (RBI, 2004) and excludes expenditure incurred under 'Secretariat and Social Services' 'Aid, Material and Equipment' and 'Capital Outlay on Housing Head'. Hence, the data are not exactly comparable with the data presented earlier. 


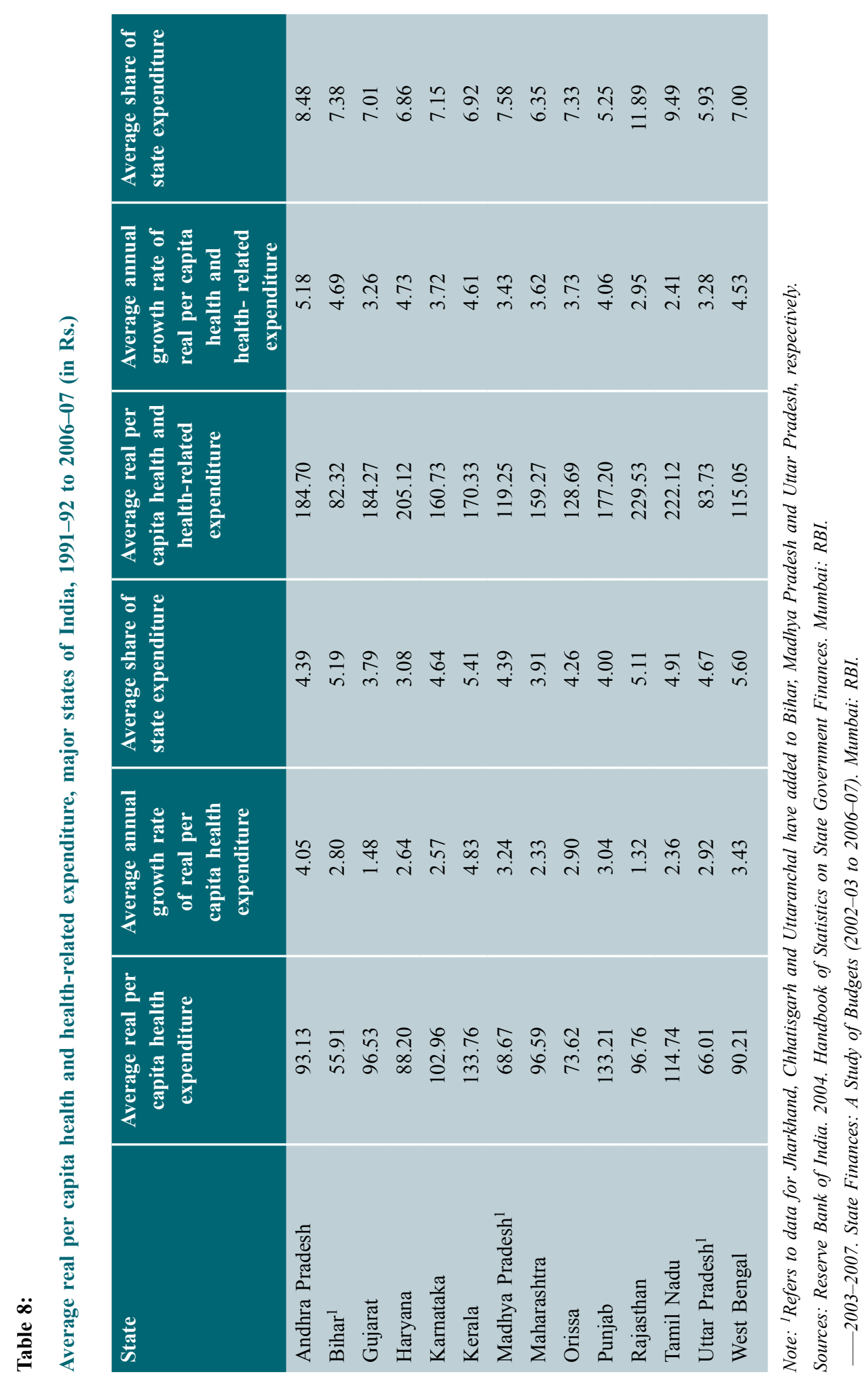

15 Public Expenditure on Health Care in Orissa: Focus on Reproductive and Child Health Services 
During 1990-91 to 2006-07, with a real per capita health expenditure of Rs. 74, Orissa ranked eleventh among the major states of India; the only states that ranked below Orissa were Madhya Pradesh (Rs. 69), Uttar Pradesh (Rs. 66) and Bihar (Rs. 56). Further, with a 3 percent average annual growth rate of real per capita health expenditure and an average share of 4 percent of its total expenditure on health, Orissa ranked seventh and tenth, respectively, among the major states.

Table 8 also shows that during the same period, Orissa ranked tenth among the major states, with an average real per capita health and health-related expenditure of Rs. 129. Likewise, the state's average real per capita health and health-related expenditure grew by about 4 percent, making it the seventh highest among the major states, while in terms of its average share ( 7 percent) of the total state spending on health and health-related matters, it ranked sixth among the states.

\section{Composition of health expenditure}

This section provides a detailed analysis of the total health expenditure incurred by the Health and Family Welfare Department and other departments, by major heads, submajor heads, minor heads, plan and non-plan expenditure, type of inputs and health care functions. It excludes resources routed outside the state budget (that is, off budget expenditure shown earlier in Table 5).

\section{Health expenditure by major heads}

As described in the section on Methodology, the major heads of health expenditure of the Health and Family Welfare Department included (1) Medical and Public Health; (2) Family Welfare; (3) Secretariat and Social Services; (4) Aid, Materials and Equipments; (5) Capital Outlay on Medical and Public Health; and (6) Capital Outlay on Housing.

Table 9 presents the expenditure on health incurred under these six major heads of expenditure during 1996-97 to 2007-08. 'Medical and Public Health' accounted for the largest share of the total health expenditure under these six heads-between 67 and 83 percent, increasing from 73 percent in 1996-97 to 83 percent in 2007-08. Expenditure under the 'Family Welfare' head ranked second; it made up 21 percent of the total spending in 1996-97, remained around 20 percent up to 1998-99, and declined gradually thereafter to touch 15 percent in 2007-08 (BE). One of the reasons for this decline is the reduction in the contribution of the central government to the family welfare programme. The decline from 2005-06 onward was because most components of the family welfare programmes were merged with the NRHM, and NRHM funds do not form a part of the state budget but are transferred directly to the societies.

Table 9 also shows that not only was the proportion of capital expenditure in the total health budget meagre — not more than 7.5 percent during the study period—but the spending pattern was also inconsistent. Thus, while the percentage of capital expenditure fell from 5 percent of the total expenditure in 1996-97 to 4 percent in 2005-06, barely 2 percent of the total health expenditure was allocated for capital outlay on medical and 


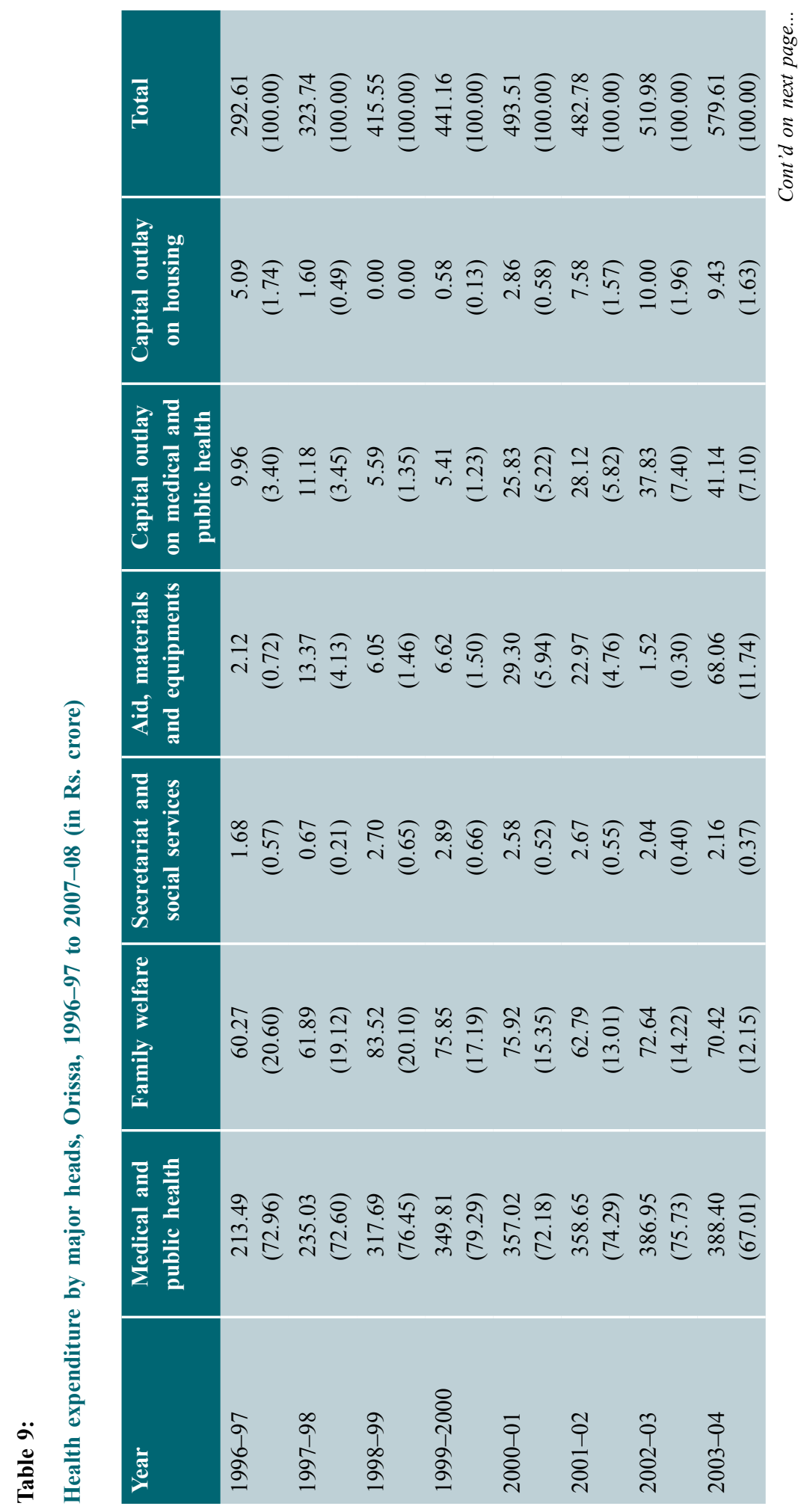

17 Public Expenditure on Health Care in Orissa: Focus on Reproductive and Child Health Services 


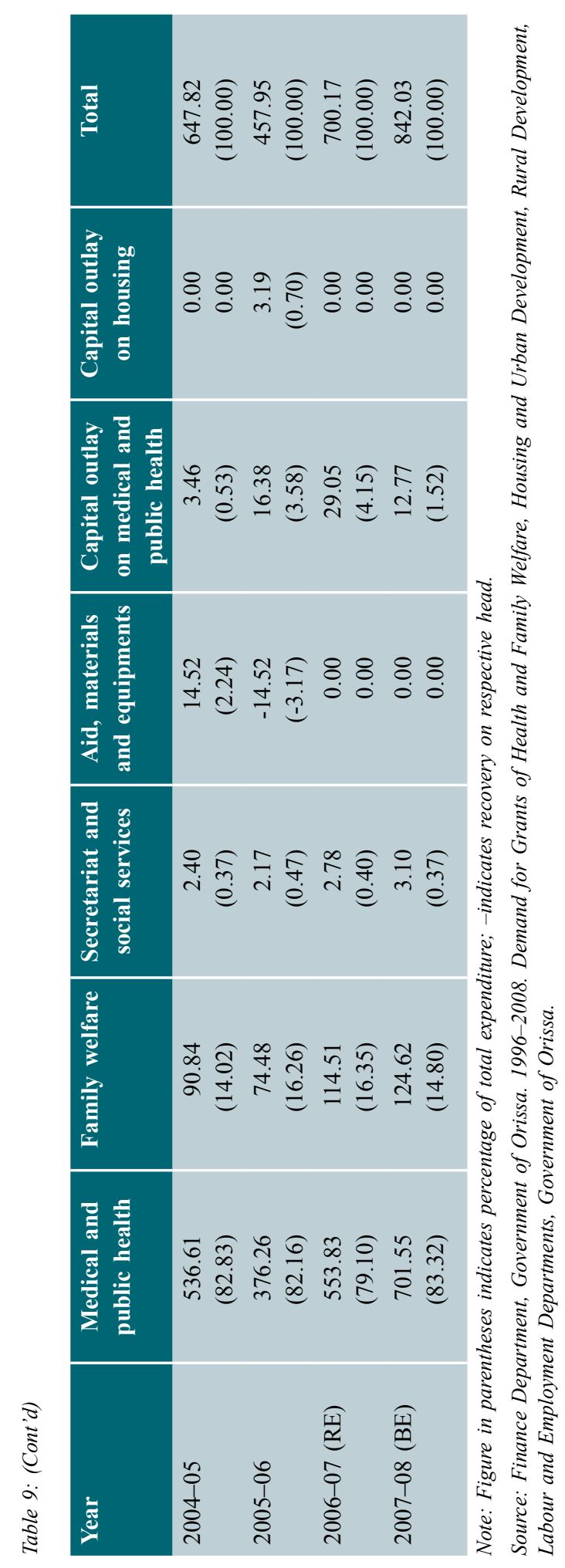

18 Sarit Kumar Rout 
public health and no funds were allocated for capital outlay on housing for two successive years-2006-07 and 2007-08. This suggests low or hardly any new investment in public health which would necessarily affect the creation of much-needed basic physical infrastructure in the state, a fact substantiated by the recent DLHS-3 that reports that two-fifths (40 percent) of sub-centres in the state do not have buildings, almost half (47 percent) of the PHCs do not have buildings for in-patient care, and just 18 percent of PHCs have facilities for newborn care. Further, by and large, buildings that do exist have not been repaired properly.

\section{Health expenditure by sub-major heads}

A break-up of the total health expenditure into different sub-major heads (Table 10) explains its distribution among urban and rural health services, other systems of medicine, and medical education, and training and research activities in health care. Of these, four sub-major expenditure heads, namely, 'Urban Health Services (Allopathy)', 'Rural Health Services (Allopathy)', 'Public Health', and 'others', accounted for over 80 percent of the state's total health expenditure. The pattern remained, by and large, similar over the 12-year study period. Specifically, Urban Health Services (Allopathy) accounted for 37 percent of the total health expenditure in 2007-08, rising from 27 percent in 1996-97. During 2005-06, there was a significant decline in the total health expenditure leading to a decline in the share of each item of expenditure (Table 10).

Rural Health Services (Allopathy) accounted for much less in 2007-08-22 percent of the total health expenditure with its share remaining, by and large, the same during the study period except in 2005-06 when it increased to 34 percent. Public health activities including disease control programmes recorded the third highest share among sub-major components; varying from 10 to 15 percent during the period of analysis while 'other' expenditure explained 15 percent of the total expenditure in 2007-08, and varied from 14 to 24 percent across the same period. Other sub-major heads received fewer resources. Notably, just 6-10 percent of the total health expenditure had been expended on medical education, training and research during the last 12 years. It may be noted that most of the training activities are project specific and funds are allocated as a part of the project. Other systems of medicine, including ayurveda, homeopathy and unani received only 1-6 percent of the total resources despite the state government's commitment to promote these systems of medicine. Given its huge forest cover and 23 percent of its population comprising socio-economically deprived scheduled tribes, a poor state like Orissa would do well to allocate substantial resources to fulfil this commitment; Ayurveda and homeopathy, in particular, could be gainfully supported as they are both cost effective and affordable for many.

Similarly, just 2 percent or less of the total health expenditure was allocated for residential buildings and indeed, it did not receive any allocation during the last three years of the study period (Table 10). The lack of appropriate accommodation facilities is a major reason inhibiting doctors and paramedical staff from residing at health facility level. For example, as per the recent DLHS-3, only 53 percent of PHCs have residential quarters for doctors. This is of particular concern, given that Orissa's rural and even urban populations depend almost entirely on public health care facilities for out- and in-patient care. 


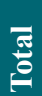

б)

ปे

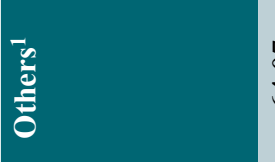

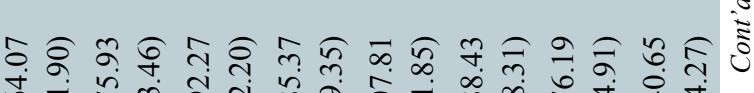

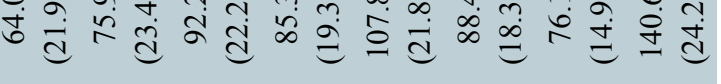

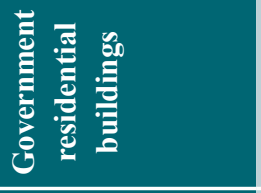

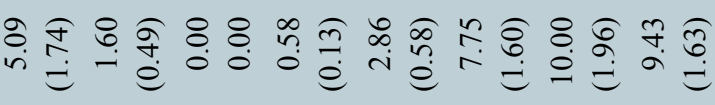

ॠ

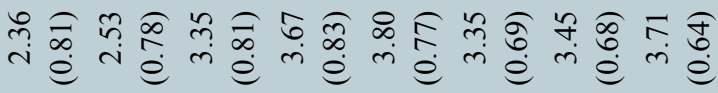

อับ

을 흘

ळ

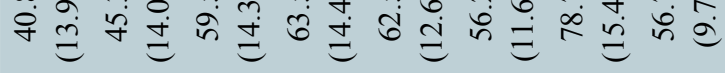

戸

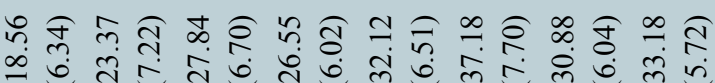

$\Xi$

$\infty$

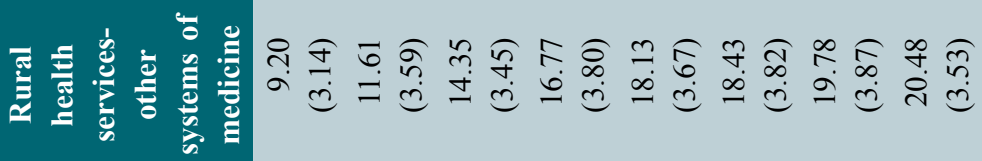

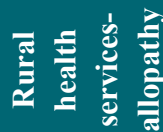

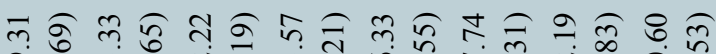

वे

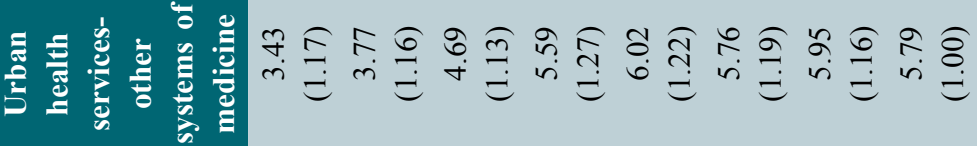

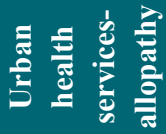

๙

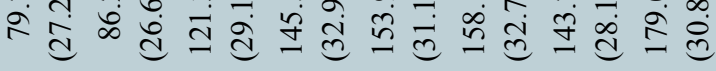

总

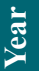

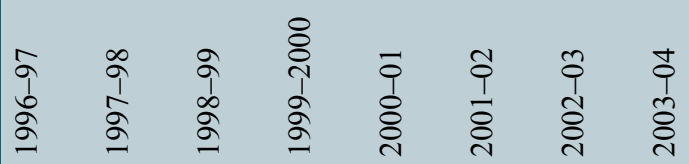




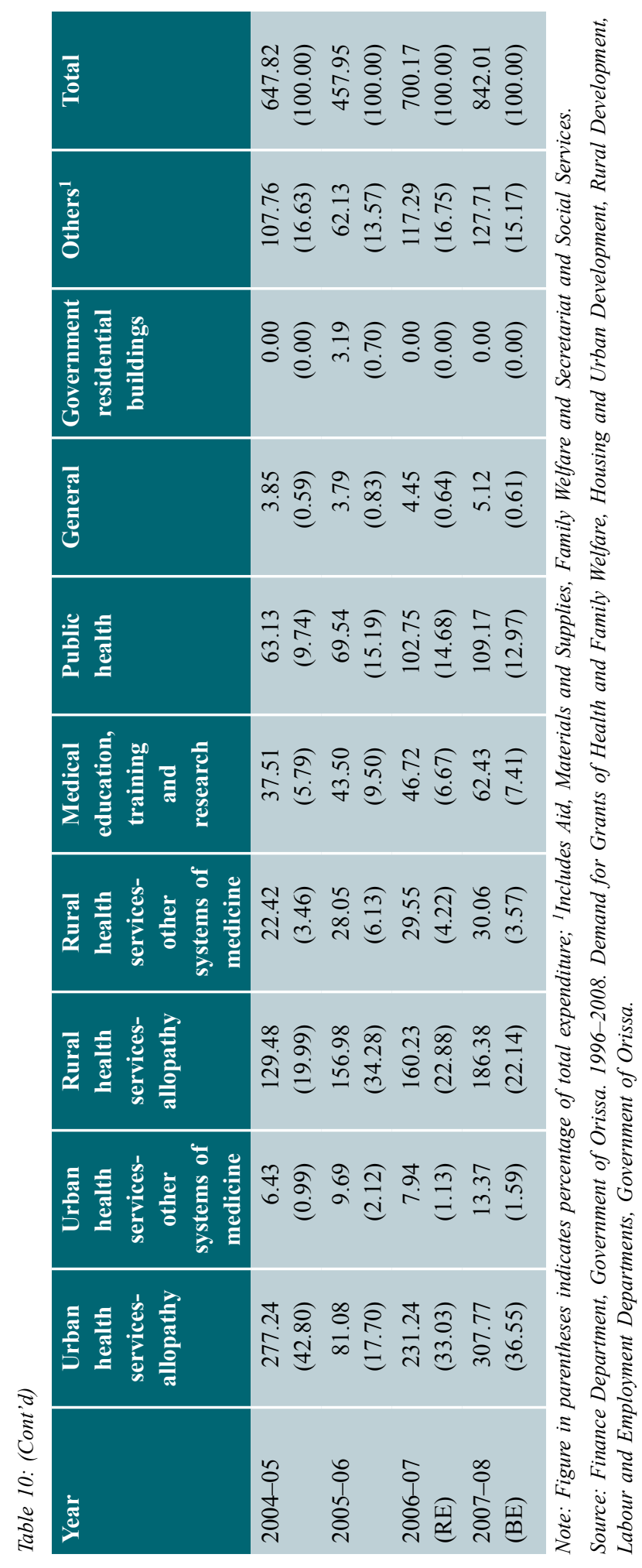

21 Public Expenditure on Health Care in Orissa: Focus on Reproductive and Child Health Services 
Further, 'Medical Education and Research' is another important area in which resources have to be stepped up. There are only three medical colleges (with a total of 450 seats) in the government sector and private sector participation in medical education is limited (although, in recent years, the state government has undertaken various initiatives to encourage public-private partnerships in medical education). Given the gap between the demand for and supply of doctors in government run health care institutions, the state needs to create more seats in medical colleges and emphasise research activities in health care.

\section{Health expenditure by minor heads}

Table 11 presents health expenditure disaggregated by minor heads of expenditure while Table 12 expresses the expenditure under these heads as a percentage of the total health expenditure. Findings suggest that the 'Hospital and Dispensaries' head that covers the expenses of medical college hospitals; district, sub-divisional and area hospitals; and specialty hospitals received the highest resource allocation in 2007-08 - one-fifth of the total health expenditure.This remained more or less constant between 23 and 25 percent during the study period except in 2004-05 when it declined (17 percent) and in the subsequent year, when it registered an increase (33 percent). The head 'Primary Health Centres' ranked second, rising from 13 percent of the health expenditure in 1996-97 to 19 percent in 2007-08, and by and large, remaining steady throughout the 12-year period, except in 2005-06 when it increased to 27 percent. Other health care facilities such as community health centres and sub-centres received less than 1 percent during the entire 12-year period.

With regard to resource allocation for various programmes, findings indicated that 9 percent of the total health expenditure was allocated for the prevention and control of diseases in 2007-08; with a range of 6-11 percent during the 12-year reference period. Similarly, in the same year, 7 percent of the resources were allocated for rural family welfare services, which remained, by and large, around 6-9 percent during this period. Other programmes such as urban family welfare services and maternal and child health services received hardly any resources - each received less than 1 percent of the total health expenditure during the last 12 years.

Finally, expenditure on direction and administration ranged between 5 and 16 percent of the total health expenditure; it stood at 16 percent in 2007-08 and at 30 percent in 2004-05. Such components as training, however, received less than 1 percent of the total resources expended during the study period (Tables $11 \& 12$ ).

\section{Health expenditure by plan and non-plan heads}

The break-up of health expenditure into plan and non-plan heads shows the proportion of the total expenditure available for introducing new schemes and programmes during a plan period after meeting committed liabilities such as salaries and other administrative expenses described as non-plan expenditure. The size of the plan expenditure has its own relevance in that it indicates the financial space available for introducing new schemes after meeting regular expenses. 


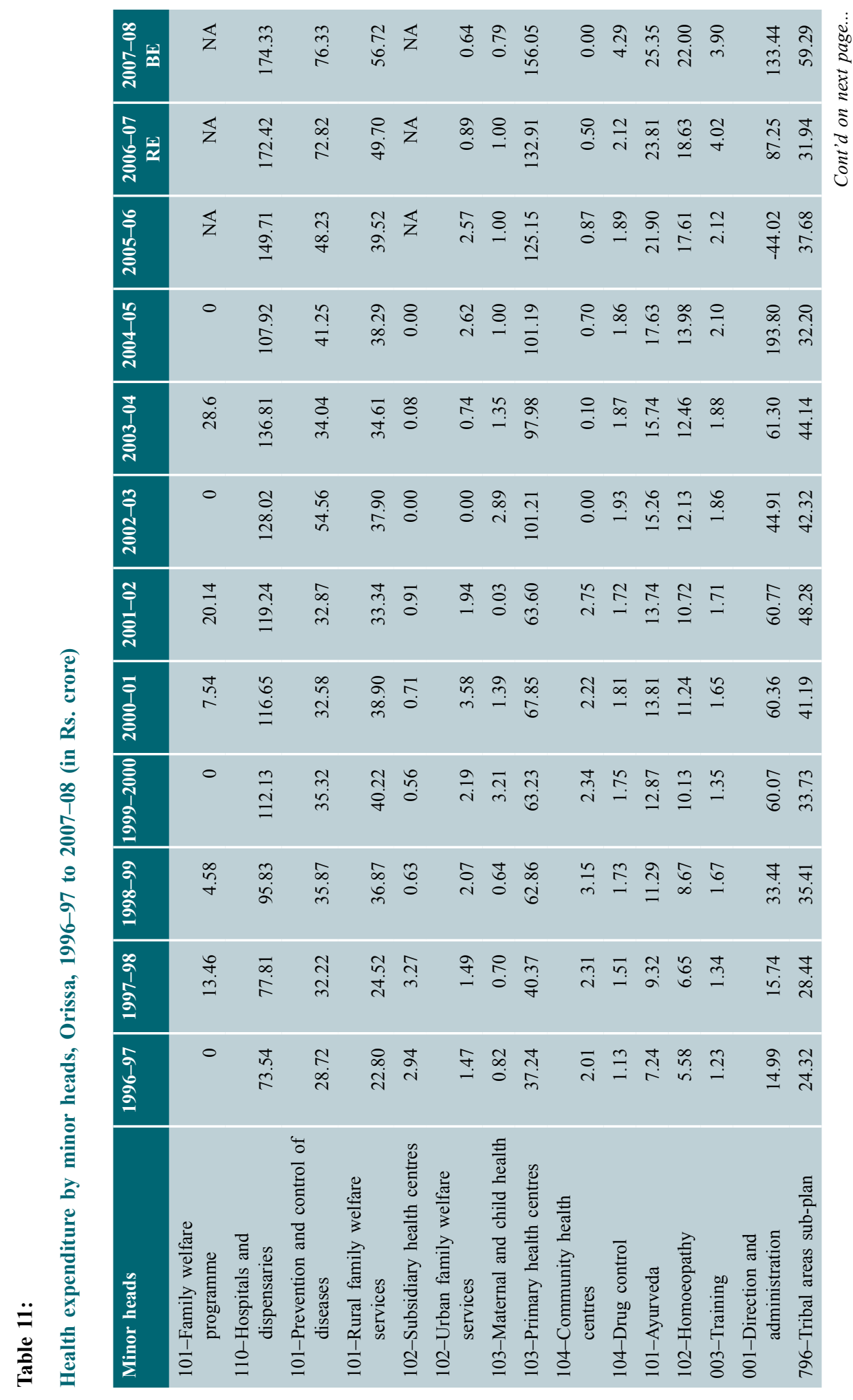

23 Public Expenditure on Health Care in Orissa: Focus on Reproductive and Child Health Services 


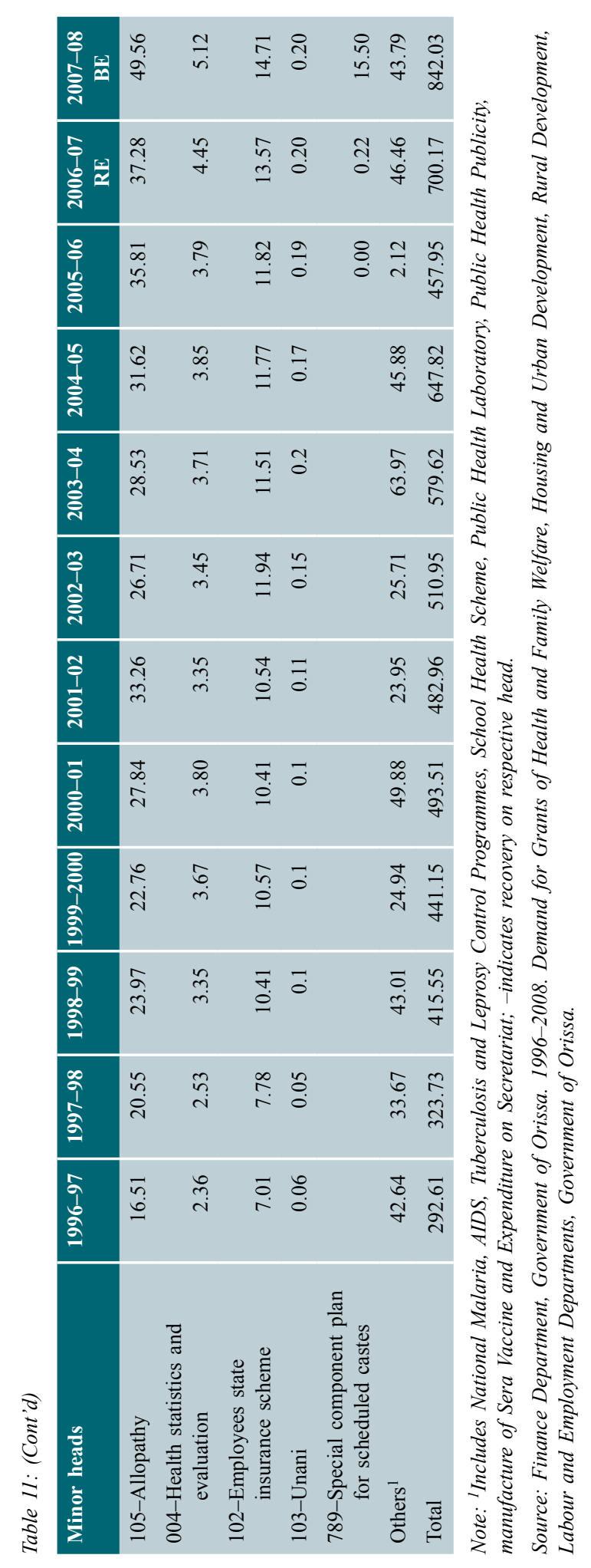

24 Sarit Kumar Rout 


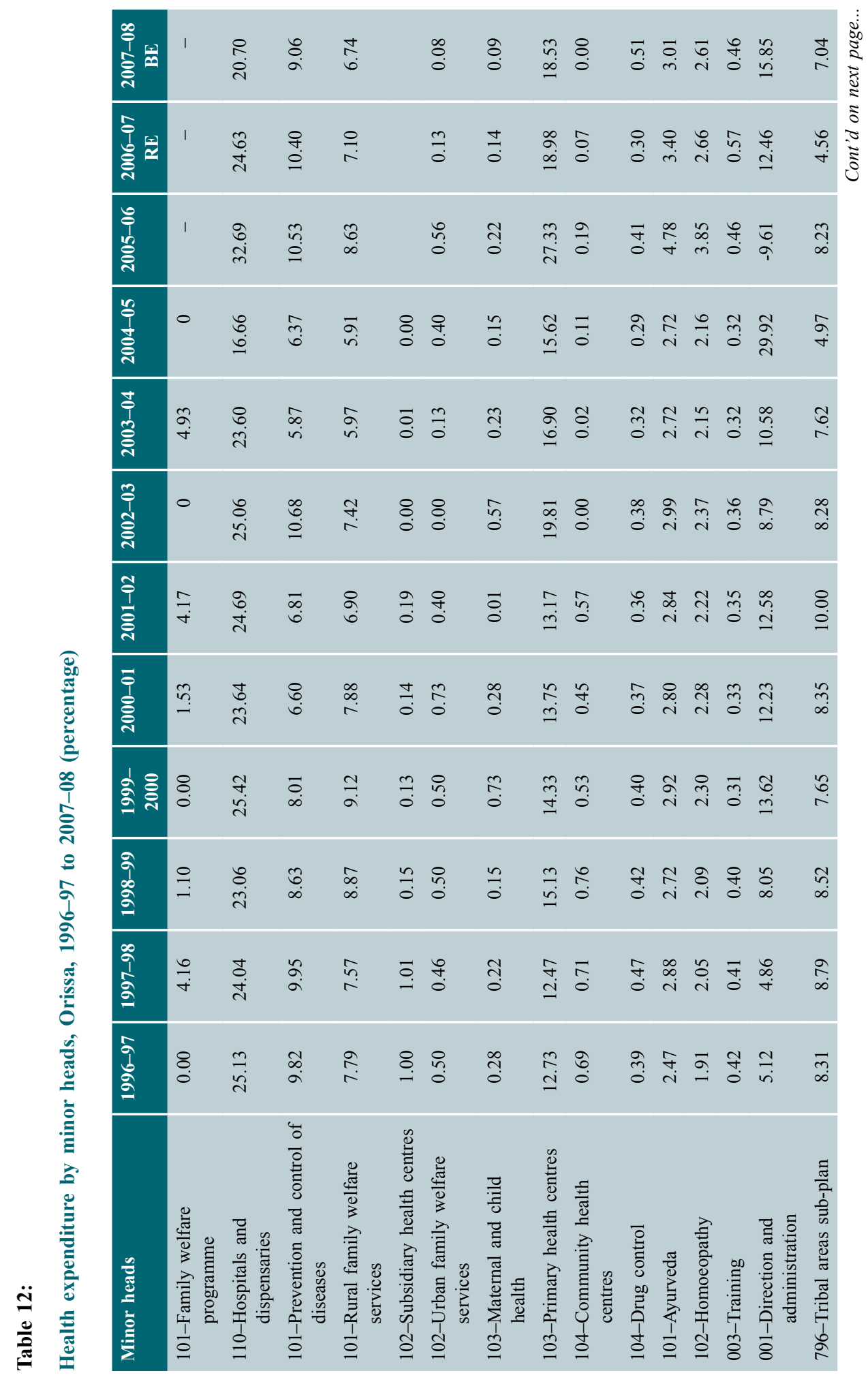




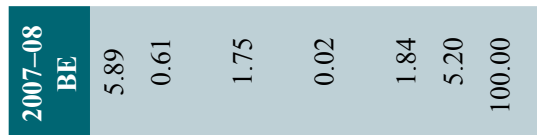

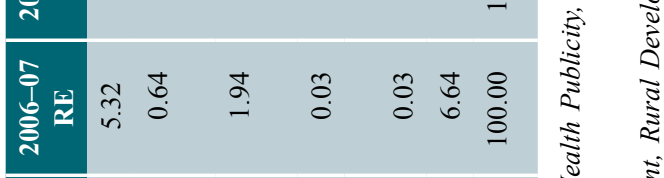

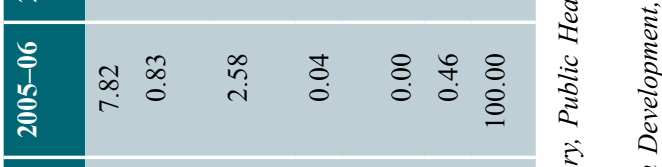

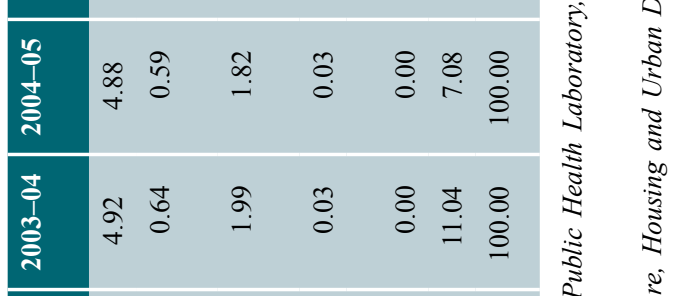

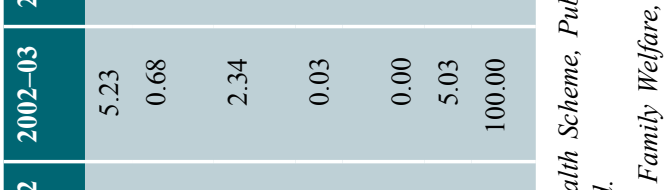

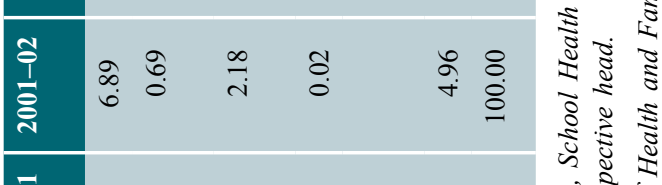

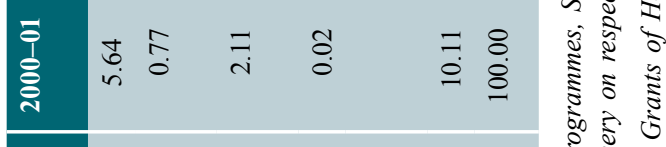

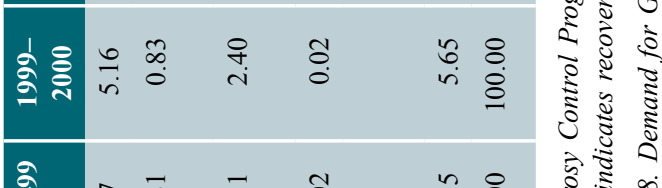

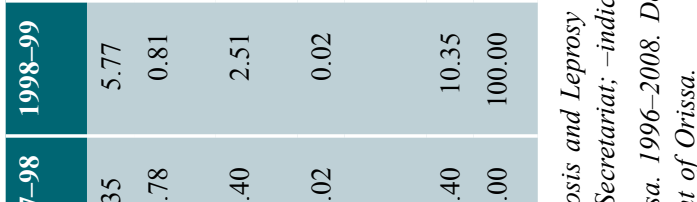

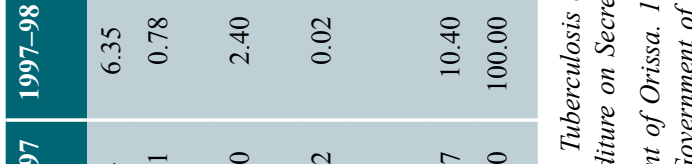

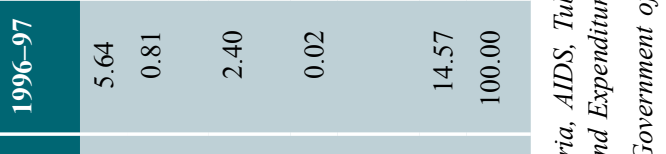

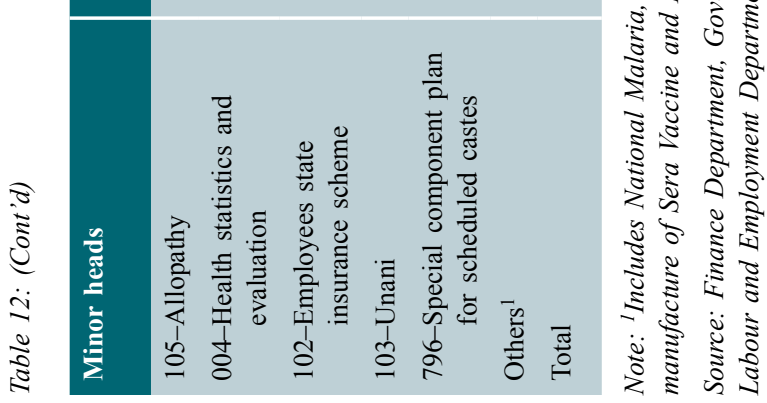$$
26 \text { Sarit Kumar Rout }
$$ 
The Orissa government has a limited plan size because the state has been afflicted by a serious financial crisis for the last several years. Plan expenditure accounted for 39 percent of the total health expenditure in 1996-97, fluctuated between 30-43 percent up to 2003-04, and reached 42 percent in 2004-05. It declined sharply in 2005-06, and again showed an upward trend thereafter (Table 13). On the other hand, non plan expenditure increased from 62 percent in 1996-97 to 74 percent of the total health expenditure in 2007-08 (BE). The average plan expenditure was 37 percent throughout the 12-year period as against 64 percent for non plan heads. Among the various components of plan expenditure, the central plan had the highest share, mostly incurred on national disease control programmes (such as, for example, the national TB control programme, the national Malaria control programme, the national blindness control programme),

Table 13:

Plan and non-plan expenditure, Orissa, 1996-97 to 2007-08 (in Rs. crore)

\begin{tabular}{l|r|r|r|}
\hline Year & Plan & Non-plan & Total \\
\hline $1996-97$ & 114.78 & 177.85 & 292.62 \\
& $(39.22)$ & $(60.78)$ & $(100.00)$ \\
$1997-98$ & 133.90 & 189.83 & 323.74 \\
& $(41.36)$ & $(58.64)$ & $(100.00)$ \\
$1998-99$ & 166.80 & 248.76 & 415.56 \\
& $(40.14)$ & $(59.86)$ & $(100.00)$ \\
$1999-2000$ & 161.06 & 280.10 & 441.17 \\
& $(36.51)$ & $(63.49)$ & $(100.00)$ \\
$2000-01$ & 213.08 & 280.43 & 493.51 \\
& $(43.18)$ & $(56.82)$ & $(100.00)$ \\
$2001-02$ & 208.50 & 274.68 & 483.18 \\
& $(43.15)$ & $(56.85)$ & $(100.00)$ \\
$2002-03$ & 154.47 & 356.44 & 510.91 \\
& $(30.23)$ & $(69.77)$ & $(100.00)$ \\
$2003-04$ & 229.42 & 350.19 & 579.62 \\
& $(39.58)$ & $(60.42)$ & $(100.00)$ \\
$2004-05$ & 273.82 & 374.00 & 647.81 \\
& $(42.27)$ & $(57.73)$ & $(100.00)$ \\
$2005-06$ & 37.68 & 420.27 & 457.95 \\
& $(8.23)$ & $(91.77)$ & $(100.00)$ \\
$2006-07$ (RE) & 176.24 & 523.93 & 700.17 \\
& $(25.17)$ & $(74.83)$ & $(100.00)$ \\
$2007-08$ (BE) & 256.03 & 586.00 & 842.03 \\
& $(30.41)$ & $(69.59)$ & $(100.00)$ \\
& & &
\end{tabular}

Note: Figure in parentheses indicates percentage of total expenditure.

Source: Finance Department, Government of Orissa. 1996-2008. Demand for Grants of Health and Family Welfare, Housing and Urban Development, Rural Development and Labour and Employment Departments, Government of Orissa. 
and the family welfare and reproductive child programmes. The sharp reduction in plan expenditure in 2005-06 has resulted from under-utilisation of resources in such heads as the prevention and control of diseases (some schemes), public health programmes, urban health services (allopathy), rural health services (allopathy) and family welfare programmes; for the most part, vacant posts, delayed approval for new posts, delays in sanction of funds by the government have been identified as key reasons for this under-utilisation (Comptroller and Auditor General of India, 2006). A reduction in the share of plan expenditure in recent years has been largely due to a reduction in the amount of grant received from the centre through the treasury route, particularly after the introduction of the NRHM whereby the grant is sent directly to the state societies.

\section{Health expenditure by type of inputs}

This section discusses expenditure on salaries, diet, medicines etc by the Health and Family Welfare Department alone. As seen from Table 14 which presents a break-up of health expenditure by the type of inputs available, a major proportion of the department's total spending during the period under study was on salaries and wages. For example, this head accounted for two-thirds of the total health expenditure in 2007-08; the trend in spending remained steady, for the most part - at over 70 percent of the total expenditure from 1996-97 to 2002-03 but fluctuated considerably thereafter. Important items such as medicines, diet, bedding and clothing which directly benefit patients received meagre resources throughout the study period. On average, while the state government had spent Rs. 15.74 crore per year for medicines during the last 12 years, as a share of the department's total expenditure it was only 3.31 percent. This is disturbingly low; moreover, the downward trend in spending from 4.16 percent in 1996-97 to 2.29 percent in 2007-08 (BE) in an era of high drug prices and particularly in a state with a high dependence on public health care institutions is of grave concern. Indeed, evidence that a large proportion of out-of-pocket expenditure incurred for in-patient care was for the purchase of drugs -72 percent and 78 percent in rural and urban areas of Orissa, respectively - indicates the large amounts that people, most of whom can ill afford it, are compelled to spend on medicines (MOHFW, 2007). 


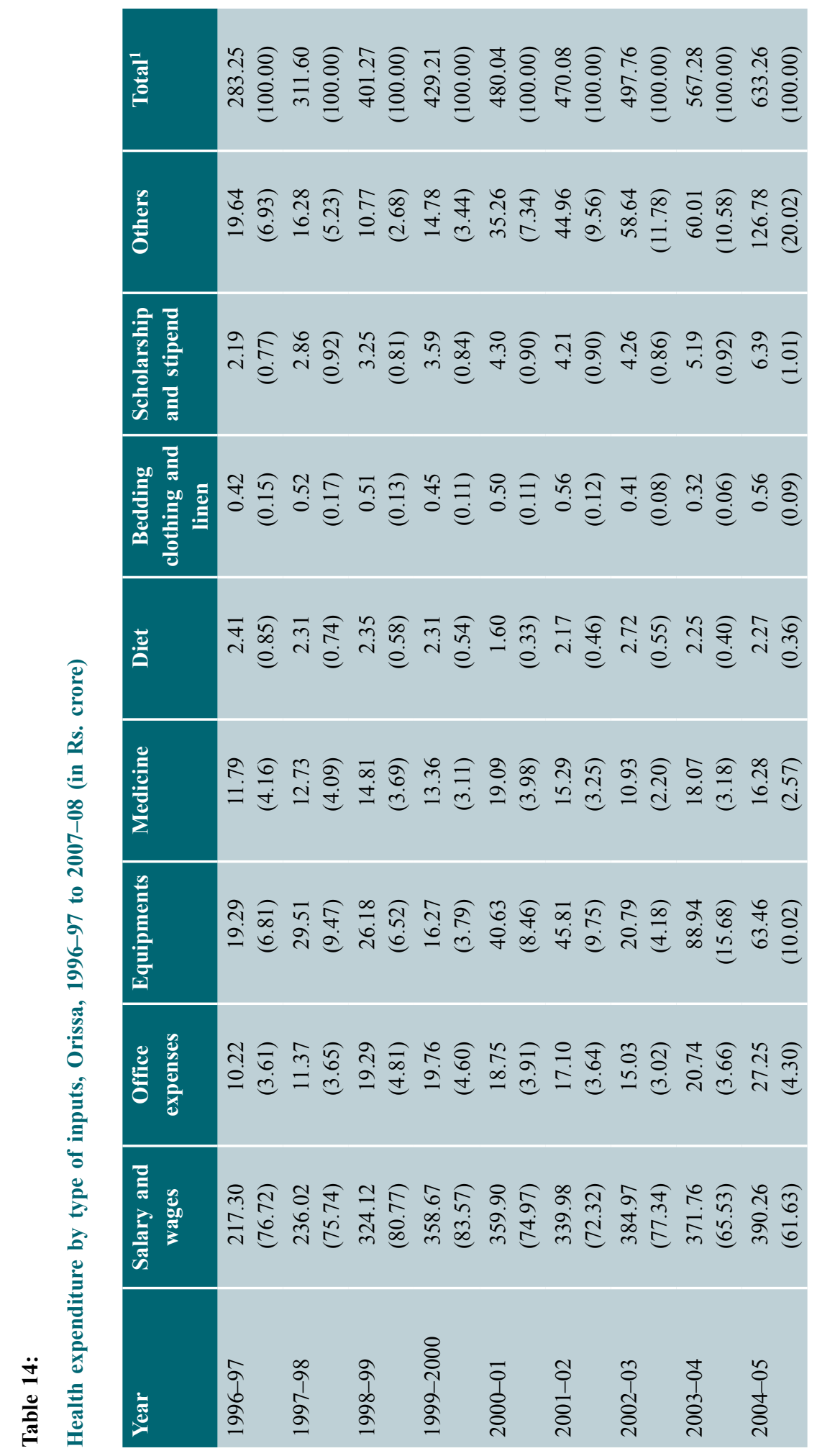

29 Public Expenditure on Health Care in Orissa: Focus on Reproductive and Child Health Services 


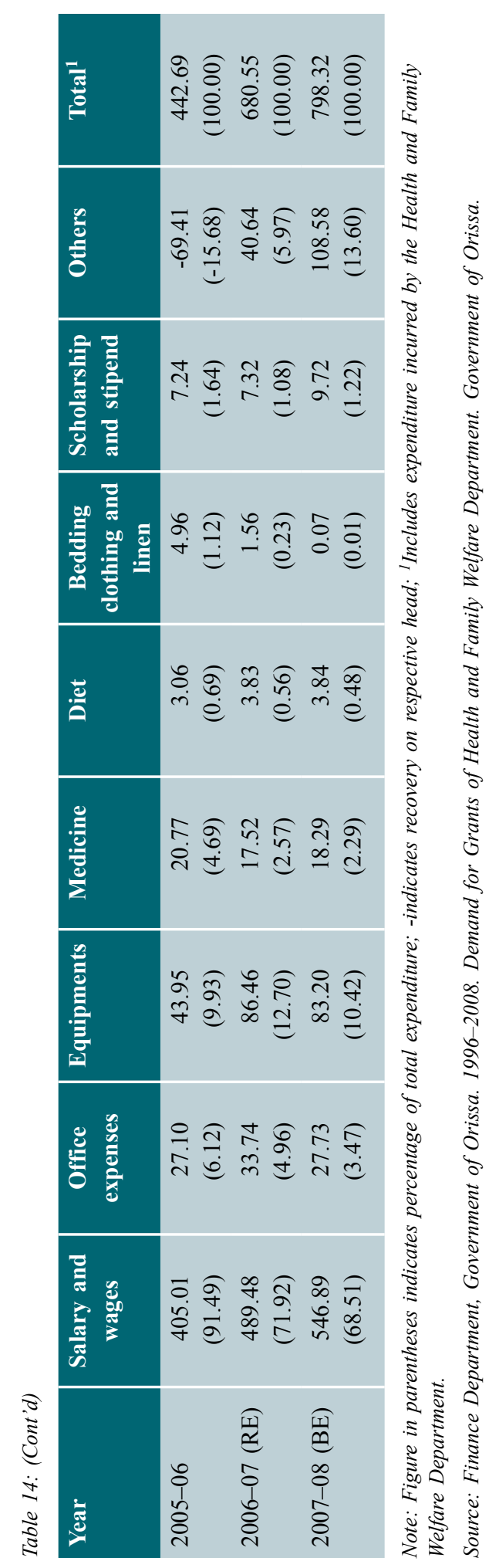

30 Sarit Kumar Rout 


\section{Health expenditure by type of health care function}

Table 15 presents the expenditure on the type of health care functions, namely, primary, secondary, tertiary and 'direction and administration', as a percentage of the total spending. Health expenditure by function and its classification have been explained in Appendix 1. Primary care accounted for over half of the total health expenditure incurred by the Health and Family Welfare Department, except in 2004-05 when it accounted for only 45 percent while in case of secondary and tertiary care, it ranged from 12-23 percent, and 12-14 percent, respectively. These findings suggest that the norms of primary and tertiary care in the total health expenditure stipulated in the State Integrated Health Policy 2002 (55 and 10 percent, respectively) were, by and large, followed. The allocation of secondary care, however, fell considerably short of its norm of 35 percent.

\section{Table 15:}

Health expenditure by health care function, Orissa, 2002-03 to 2007-08 (percentage)

\begin{tabular}{|l|c|c|c|c|c|}
\hline Year & Primary & Secondary & Tertiary & $\begin{array}{c}\text { Direction and } \\
\text { administration }\end{array}$ & Total $^{1}$ \\
\hline 2002-03 & 53.62 & 22.71 & 13.78 & 9.89 & 100 \\
$2003-04$ & 57.48 & 17.45 & 13.54 & 11.53 & 100 \\
$2004-05$ & 44.71 & 12.04 & 11.95 & 31.29 & 100 \\
2005-06 (RE) & 52.52 & 16.10 & 15.32 & 16.05 & 100 \\
2006-07 (RE) & 52.09 & 20.20 & 12.94 & 14.77 & 100 \\
2007-08 (BE) & 50.51 & 14.67 & 13.39 & 21.42 & 100 \\
Average & 51.82 & 17.20 & 13.49 & 17.49 & -
\end{tabular}

Note: ${ }^{I}$ Includes expenditure incurred by the Health and Family Welfare Department.

Source: Finance Department, Government of Orissa. 1996-2008. Demand for Grants of Health and Family Welfare Department. Government of Orissa.

\section{Differences between budget estimates and actual expenditure}

Table 16 presents data on budget estimates and actual expenditure on health incurred by the Health and Family Welfare Department. Findings indicate that actual spending fell short of the budget estimates during the period 2000-01 to 2006-07. Notably, in 2005-06, only 60 percent of the budget was utilised. On average, during the 12-year study period, the state utilised 84 percent of the total budgeted amount. Such inconsistency in spending questions the efficiency of the administrative machinery to utilise funds. As discussed earlier, non plan expenditure accounted for $65-70$ percent of the total health expenditure and its utilisation does not pose any problem as it mostly pertains to salaries and administrative expenses. Plan funds, on the other hand, are largely under-utilised. Therefore, their correct utilisation calls for good planning and execution and proper monitoring of programmes. It also requires the timely release of funds from the central to the state government, and from the state headquarters to the implementing agencies at the district and block level. Delays in the release of central funds, inappropriate planning 
at the state level without giving due consideration to ground realities, and administrative apathy often result in poor utilisation of plan funds. Thus, while demanding additional funds, the absorbing capacity of the government needs to be thoroughly examined.

\section{Table 16:}

Difference between budget estimates and actual expenditure, Orissa, 2000-01 to 2006-07 (in Rs. crore)

\begin{tabular}{|c|c|c|c|}
\hline Year & Budget estimate & Actual expenditure & $\begin{array}{c}\text { Percentage of actual } \\
\text { over budget estimate }\end{array}$ \\
\hline $2000-01$ & 523.56 & 480.04 & 91.69 \\
$2001-02$ & 555.53 & 470.08 & 84.62 \\
$2002-03$ & 616.38 & 497.76 & 80.76 \\
$2003-04$ & 600.70 & 567.28 & 94.44 \\
$2004-05$ & 702.60 & 633.26 & 90.13 \\
$2005-06$ & 740.66 & 442.69 & 59.77 \\
$2006-07$ & 677.36 & 590.55 & 87.18 \\
Average & 630.97 & 515.19 & 84.08 \\
\hline
\end{tabular}

Source: Finance Department, Government of Orissa. 2002-2007. Demand for Grants of Health and Family Welfare Department. Government of Orissa.

\section{Public expenditure on reproductive and child health services}

The present study examines the proportion of resources meant for reproductive health vis-a-vis the heads of expenditure both within and outside the budget. Within the major expenditure head of 'medical and public health; two sub-major heads namely, 'urban health services (allopathy)' and 'rural health services (allopathy)', have some component of reproductive and child health (namely, the Institute of Paediatrics, Cuttack, and maternity and child welfare centres, respectively). Thus, as defined earlier (see Methodology), reproductive and child health expenditure included the entire expenditure under the 'family welfare' head; the expenditure on nutrition except that incurred on the mid-day meal scheme of the Department of Women and Child Health; as also the RCH II, pulse polio and immunisation expenditure heads outside the budget (Appendix II).

Data presented in Table 17 indicate that the public expenditure on reproductive and child health services has tripled from Rs. 108 crore in 1996-97 to Rs. 336 crore in 2007-08. In real terms, however, the increase was only 5.09 percent. While the expenditure fluctuated from 1996-97 to 2004-05, it increased thereafter largely due to the increase in allocations routed outside the state budget and in the expenditure on nutrition. Contributions from the Health and Family Welfare Department accounted for between almost half and two-thirds of the total expenditure on reproductive and child health services from 1996-97 to 2004-05, but declined thereafter to between one-quarter and two-fifths of the total as a result of an increase in off-budget spending particularly after the introduction of NRHM funds which comprise a substantial share of $\mathrm{RCH}$ expenditure. 


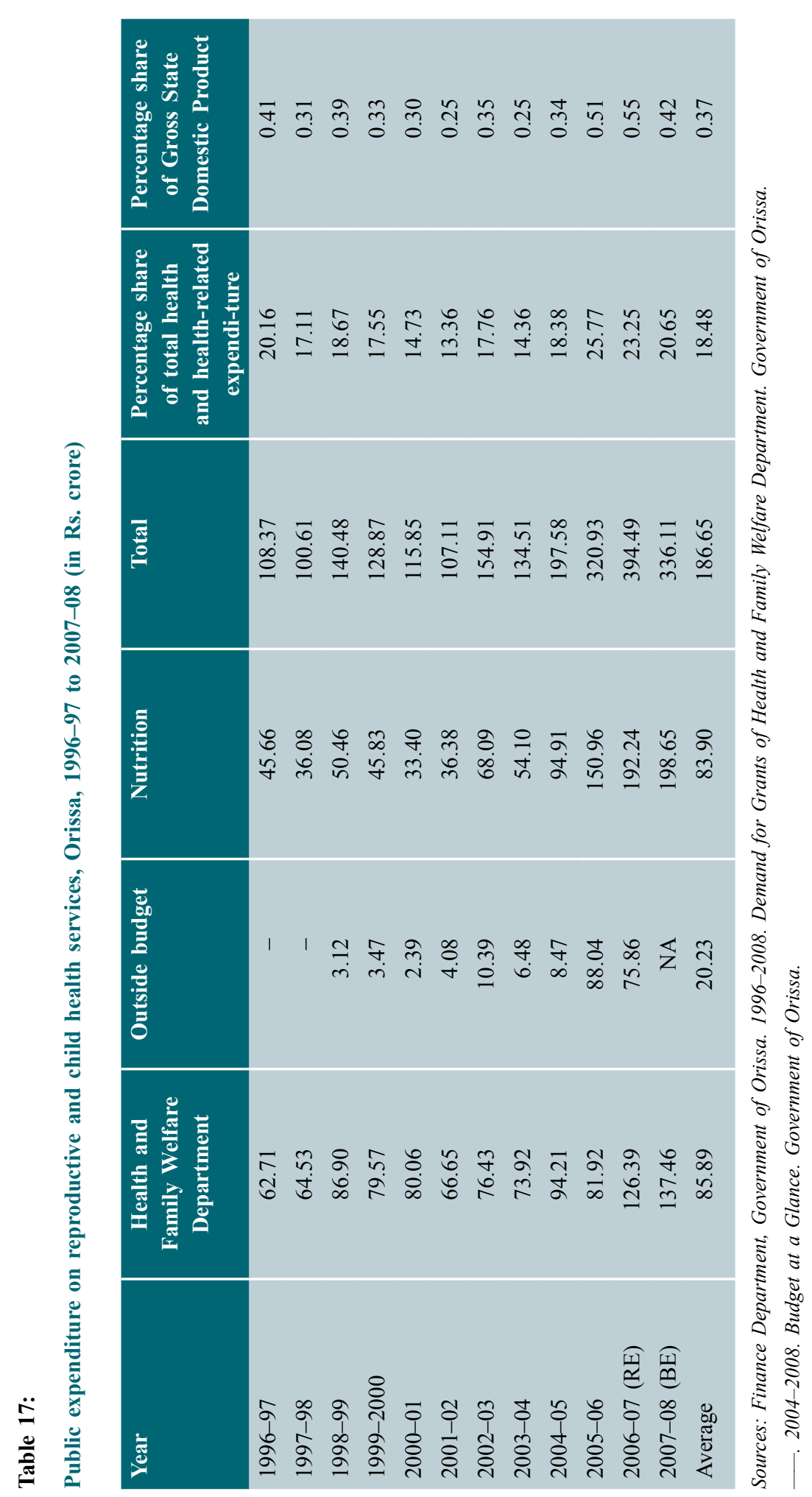

33 Public Expenditure on Health Care in Orissa: Focus on Reproductive and Child Health Services 
Figure 2:

Share of reproductive and child health expenditure in total health and health-related expenditure and gross state domestic product, Orissa, 1996-97 to 2007-08

Reproductive and child health and its share

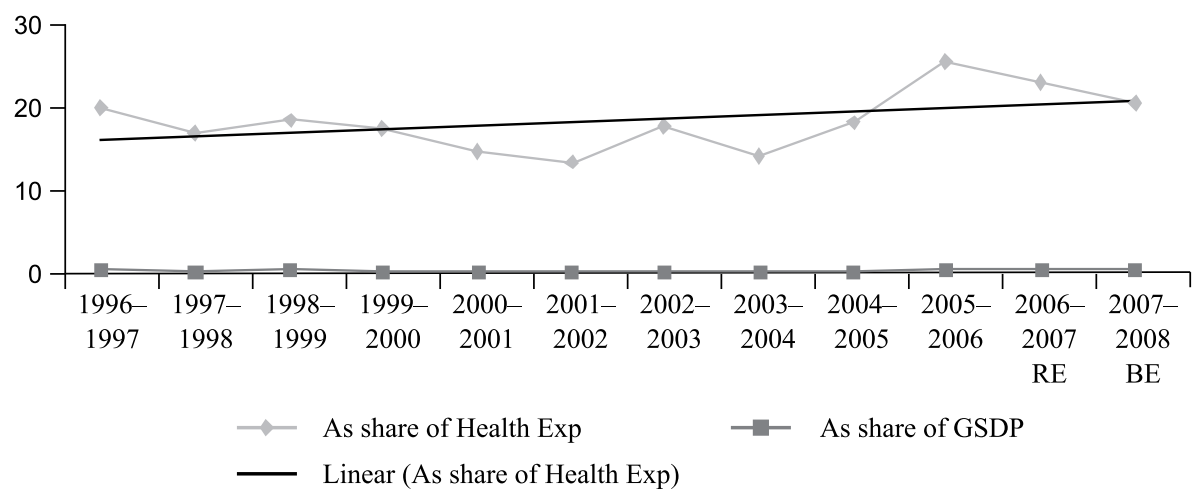

Source: Finance Department, Government of Orissa. 1996-2008. Demand for Grants of Health and Family Welfare Department. Government of Orissa.

The expenditure on reproductive and child health services fluctuated considerably during the 12-year study period. Between 13 and 26 percent of the total health and health-related expenditure was allocated for reproductive and child health services; in the most recent year, 2007-08, it was 21 percent. Nonetheless, as a share of gross state domestic product, expenditure on reproductive and child health services remained below 1 percent throughout this period.

Central government contributions comprised as much as 70-95 percent of the expenditure on reproductive and child health services during 1996-97 to 2007-08, with a contribution of 83 percent in 2007-08. The state government's contribution ranged from 5-21 percent during the same period and stood at 18 percent in 2007-08. While contributions from donor agencies remained modest till 2004-05, they increased thereafter. For example, 25-30 percent of the expenditure on reproductive and child health services during 2005-07 came from donor agencies. Increased donor contributions bring about greater flexibility in funding and utilisation of resources based on planning, leading to the achievement of targets within the stipulated time. While this is a clear advantage in comparison to normal budgetary spending, the main issue is that of sustainability of the programme after completion of the project cycle.

Tables 19 and 20 present a break-up of the reproductive child health expenditure incurred by the Health and Family Welfare Department alone as actuals and as a percentage of the total expenditure on reproductive and child health services, respectively. Findings indicate that of the total expenditure, a major share - between 7-13 percent was allocated for rural family welfare services and centres during 1996-97 to 2007-08. In contrast, during the same period, urban family welfare services and centres received only 2 percent or less of the total expenditure. Likewise, maternal and child health services received just 2-7 percent of the total expenditure on reproductive and child health services. Notably, scant resources were also allocated for training of health care providers -3 percent or less. 
Table 18:

Expenditure on reproductive and child health services by sources of funding, Orissa, 1996-97 to 2007-08 (percentage)

\begin{tabular}{|l|c|c|c|c|}
\hline Year & State share & Central share & Donor agencies & Total \\
\hline $1996-97$ & 5.36 & 94.64 & - & 100.00 \\
$1997-98$ & 5.81 & 94.19 & - & 100.00 \\
$1998-99$ & 7.08 & 89.46 & 3.46 & 100.00 \\
$1999-2000$ & 5.83 & 89.99 & 4.18 & 100.00 \\
$2000-01$ & 6.55 & 90.55 & 2.90 & 100.00 \\
$2001-02$ & 6.27 & 87.97 & 5.76 & 100.00 \\
$2002-03$ & 15.44 & 72.56 & 11.99 & 100.00 \\
$2003-04$ & 21.42 & 70.52 & 8.06 & 100.00 \\
$2004-05$ & 13.86 & 77.90 & 8.25 & 100.00 \\
$2005-06$ & 4.48 & 70.51 & 25.01 & 100.00 \\
$2006-07$ (RE) & 11.71 & 58.62 & 29.67 & 100.00 \\
$2007-08$ (BE) & 18.07 & 81.93 & NA & 100.00 \\
Average & 10.16 & 81.57 & 9.93 & 100.00
\end{tabular}

Sources: Finance Department, Government of Orissa. 2004-2008. Budget at a Glance. Government of Orissa.

—. 1996-2008. Demand for Grants of Health and Family Welfare Department. Government of Orissa.

\section{Figure 3:}

Expenditure on reproductive and child health services by sources of funding, Orissa, 1998-99 \& 2005-06 (percentage)

Sources of RCH Funds : 1998-99

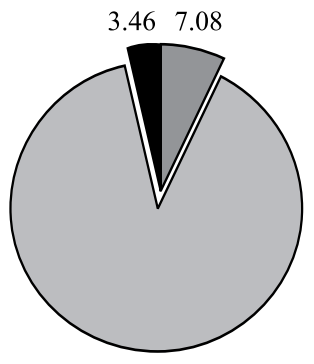

89.46
Sources of RCH Funds : 2005-06

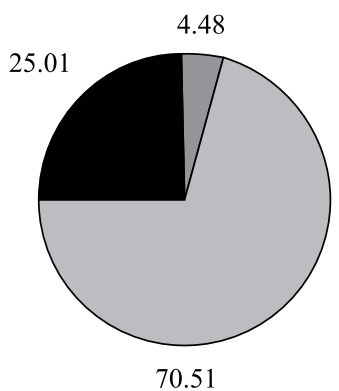

Donor Agencies

Sources: Finance Department, Government of Orissa. 2004-2008. Budget at a Glance. Government of Orissa.

—. 1996-2008. Demand for Grants of Health and Family Welfare Department. Government of Orissa. 


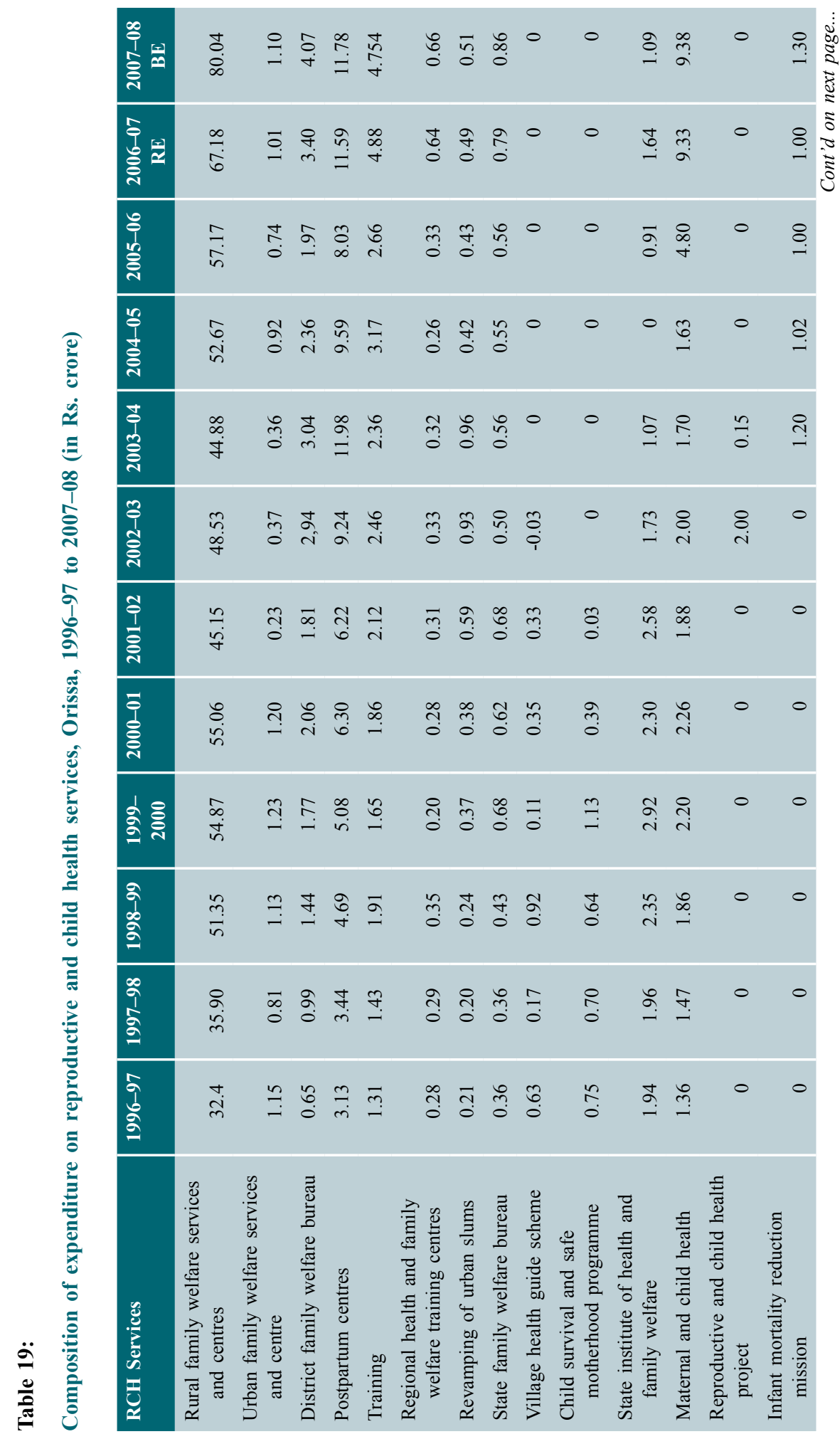




\begin{tabular}{|c|c|c|c|c|c|}
\hline 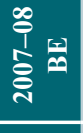 & 0 & $\begin{array}{l}8 \\
\infty \\
\infty\end{array}$ & $\stackrel{n}{m}$ & t̊. & \\
\hline 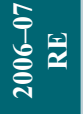 & $\underset{\stackrel{\delta}{\sigma}}{\stackrel{+}{+}}$ & $\stackrel{8}{\stackrel{8}{-}}$ & $\stackrel{\circ}{n}$ & $\begin{array}{c}\hat{\infty} \\
0 \\
0\end{array}$ & $\begin{array}{l}\text { లె } \\
\text { స్ }\end{array}$ \\
\hline 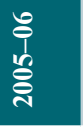 & 0 & 0 & $\begin{array}{l}\text { ț } \\
\text { i }\end{array}$ & $\begin{array}{l}\infty \\
\stackrel{0}{0}\end{array}$ & $\frac{\tilde{\sigma}}{\infty}$ \\
\hline 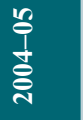 & $\begin{array}{l}\infty \\
\stackrel{n}{n}\end{array}$ & $\begin{array}{l}\hat{b} \\
\ddot{n}\end{array}$ & $\stackrel{ \pm}{\stackrel{I}{-}}$ & $\stackrel{8}{\circ}$ & $\bar{ন}$ \\
\hline 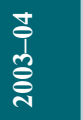 & बे & 0 & $\stackrel{\infty}{\infty}$ & "ro & مै \\
\hline ְิ & 0 & 0 & $\stackrel{t}{-}$ & $\stackrel{\circ}{\stackrel{r}{r}}$ & ? \\
\hline 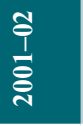 & $\stackrel{\widetilde{\sim}}{\text { ஸे }}$ & 0 & $\hat{\sigma}$ & กิ & $\begin{array}{l}\tilde{b} \\
b\end{array}$ \\
\hline 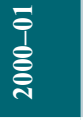 & 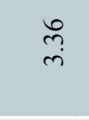 & 0 & $\stackrel{\infty}{-}$ & $\stackrel{?}{i}$ & $\begin{array}{l}\stackrel{0}{0} \\
\infty\end{array}$ \\
\hline ڤે & $\begin{array}{l}\overrightarrow{0} \\
\text { in }\end{array}$ & 0 & $\stackrel{\bar{n}}{-}$ & $\begin{array}{l}0 \\
\infty \\
0\end{array}$ & $\hat{n}$ \\
\hline $\begin{array}{l}\hat{a} \\
\hat{\alpha} \\
\hat{\sigma}\end{array}$ & $\stackrel{\hat{\sigma}}{+}$ & $\hat{n}$ & & ర్రా & $\begin{array}{l}8 \\
\infty \\
\infty\end{array}$ \\
\hline$\frac{\infty}{\hat{1}}$ & $\stackrel{m}{\dot{m}}$ & $\stackrel{g}{=}$ & $\stackrel{\infty}{=}$ & ণ̛ ฺ. & is \\
\hline 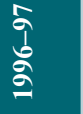 & $\stackrel{\widetilde{v}}{\sim}$ & 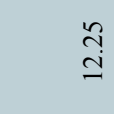 & & ̊. & $\overline{8}$ \\
\hline 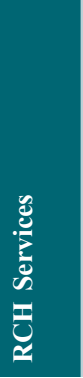 & 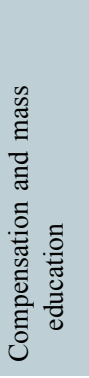 & 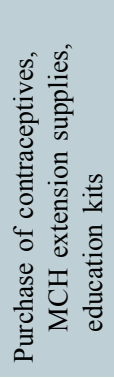 & 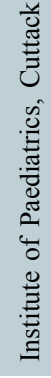 & & 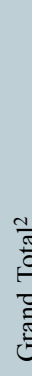 \\
\hline
\end{tabular}

37 Public Expenditure on Health Care in Orissa: Focus on Reproductive and Child Health Services 


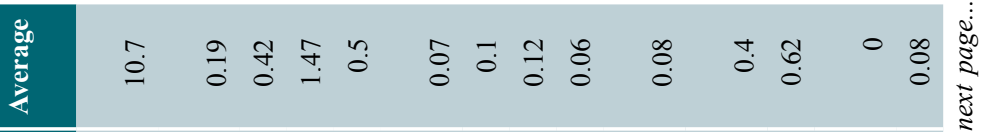

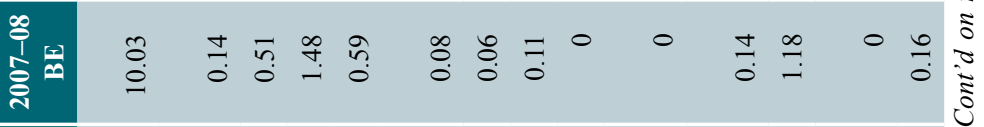

商

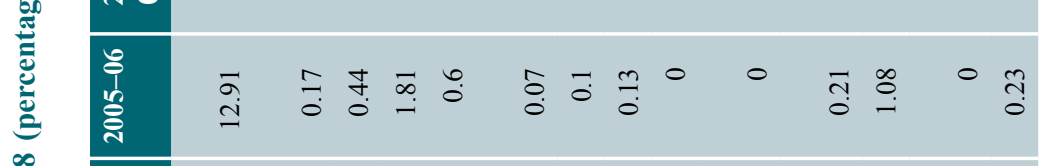

$\square$

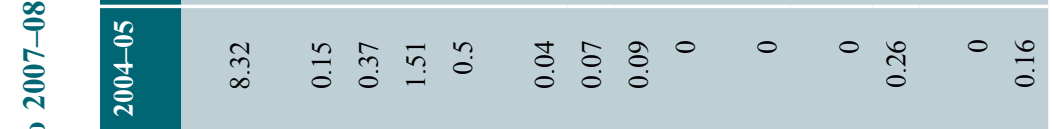

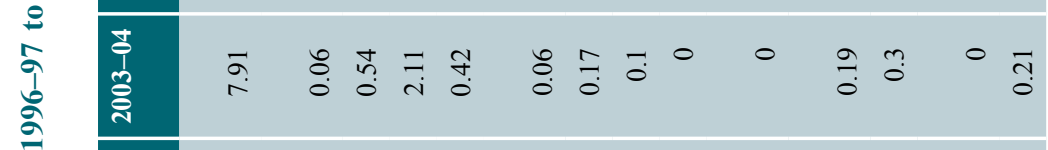

芯

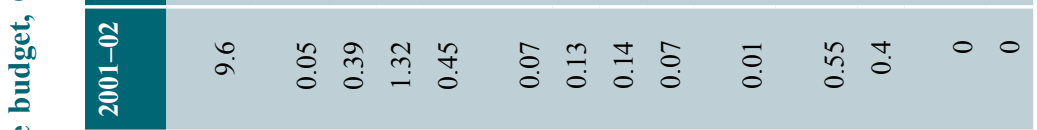

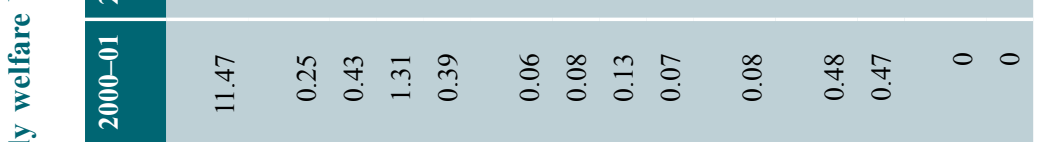

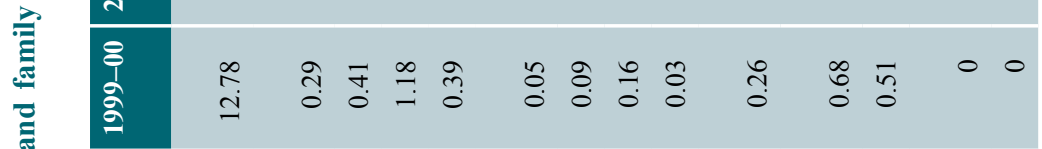

Е

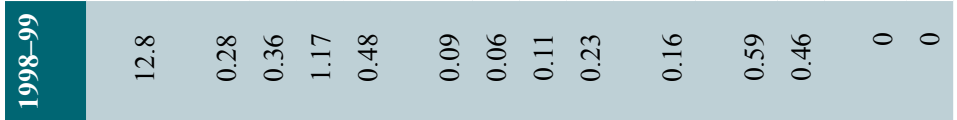

ڤొ

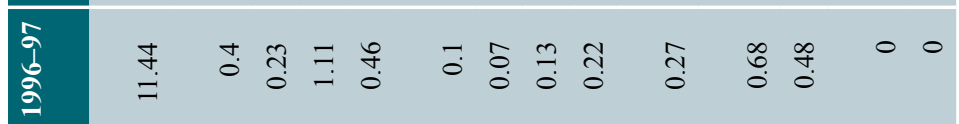

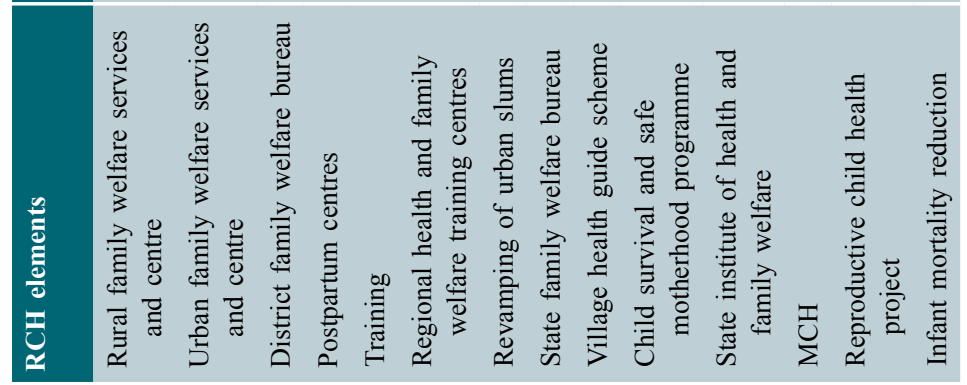

38 Sarit Kumar Rout 


\begin{tabular}{|c|c|c|c|c|c|}
\hline $\begin{array}{l}\frac{8}{80} \\
\frac{\pi}{5} \\
\frac{\pi}{0} \\
\frac{8}{4}\end{array}$ & $\begin{array}{l}n \\
0 \\
0\end{array}$ & $\stackrel{n}{n}$ & ले & $\overrightarrow{\widehat{o}}$ & 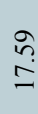 \\
\hline 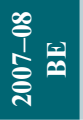 & 0 & $\stackrel{\text { ते }}{\sim}$ & $\stackrel{\text { fo }}{0}$ & $\stackrel{\circ}{\circ}$ & $\underset{N}{\stackrel{N}{I}}$ \\
\hline 党 & in & $\ddot{n}$ & $\stackrel{\infty}{0}$ & $\frac{m}{0}$ & $\begin{array}{l}\hat{n} \\
\infty\end{array}$ \\
\hline 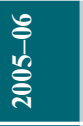 & 0 & 0 & $\stackrel{0}{\circ}$ & $\frac{n}{0}$ & $\begin{array}{l}\vec{n} \\
\infty \\
\infty\end{array}$ \\
\hline 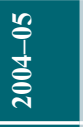 & $\tilde{n}$ & $\underset{\text { 守 }}{\text { i }}$ & $\hat{\tilde{o}}$ & $\overline{0}$ & $\begin{array}{l}\infty \\
\infty \\
\dot{J}\end{array}$ \\
\hline 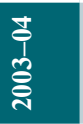 & $\hat{n}$ & 0 & กี่ & $\overrightarrow{0}$ & $\stackrel{\vec{b}}{\mathrm{~m}}$ \\
\hline 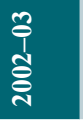 & 0 & 0 & m̊ & $\stackrel{0}{\stackrel{0}{0}}$ & $\stackrel{\circ}{\stackrel{ \pm}{ \pm}}$ \\
\hline 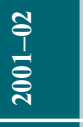 & f̊ & 0 & ปี. & $=$ & $\stackrel{\infty}{\underset{ \pm}{ \pm}}$ \\
\hline $\begin{array}{l}\overline{0} \\
1 \\
\bar{\delta} \\
\text { కิ }\end{array}$ & ôे & 0 & के? & กิ & $\begin{array}{l}\infty \\
\stackrel{0}{0} \\
\stackrel{-}{0}\end{array}$ \\
\hline $\begin{array}{l}\hat{1} \\
\hat{\theta} \\
\text { gे }\end{array}$ & $\Xi$ & 0 & ñ & $\frac{9}{0}$ & $\begin{array}{l}+ \\
\infty \\
\infty \\
\infty\end{array}$ \\
\hline $\begin{array}{l}\hat{a} \\
\text { बे } \\
\stackrel{2}{2}\end{array}$ & $\stackrel{\sigma}{-}$ & $\stackrel{m}{m}$ & $\stackrel{\infty}{m}$ & $\frac{n}{0}$ & $\stackrel{:}{\stackrel{+}{N}}$ \\
\hline$\frac{2}{\hat{a}}$ & $\stackrel{\text { Iִ }}{\text { S }}$ & $\begin{array}{l}\hat{\sigma} \\
\dot{m}\end{array}$ & $\stackrel{\infty}{3}$ & $\stackrel{m}{\circ}$ & त् \\
\hline $\begin{array}{l}\hat{a} \\
\text { bे } \\
\text { gे }\end{array}$ & 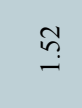 & $\stackrel{\overbrace{}}{+}$ & $\stackrel{\infty}{\tilde{0}}$ & กี & $\underset{\Xi}{\stackrel{\Xi}{d}}$ \\
\hline 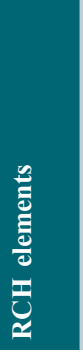 & 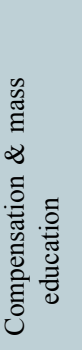 & 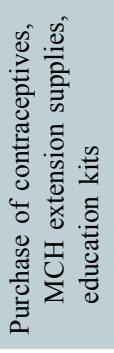 & 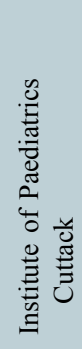 & $\overline{\overline{0}}$ & 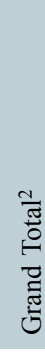 \\
\hline
\end{tabular}

39 Public Expenditure on Health Care in Orissa: Focus on Reproductive and Child Health Services 


\section{Conclusion}

The findings of the analysis of public spending on health care presented in this paper hold many significant conclusions for policy consideration.

The findings indicate that the resources allocated for health remained more or less at 4-5 percent of the state's total expenditure and just 1 percent of the gross state domestic product from 1996-97 to 2007-08. These levels of public spending are clearly less than those articulated in 2002 health policy, and would definitely influence service delivery by affecting capital expenditure and health inputs. As discussed, the outlay on capital expenditure was abysmally low compared to the vast infrastructure requirements in the state. For example, the recent DLHS-3 reveals that 40 percent of sub-centres do not have buildings, and only 18 and 53 percent of PHCs have facilities for newborn care and in-patient care, respectively. Further, the resources spent on various inputs such as medicines and diet as well as on equipments during the last 12 years, averaged 1-3 percent and 9 percent of health spending respectively. These levels are not only inordinately low but also adversely affect the poor patients visiting these health care institutions. Moreover, as much as 72 percent and 78 percent of total out-of-pocket expenditure in rural and urban areas for in-patient care in Orissa is spent on drugs and this is in the context of low drug spending by the government (MOHFW, 2007). Such high levels of private spending is regressive and questions the adequacy of public spending for effectively protecting the large segment of the poor who are forced to spend on health care.

Although contributions from the state's own resources accounted for most of the public expenditure on health, its share has declined in recent years and concomitantly, contributions from the central government and external agencies have increased. For example, contribution from externally-funded projects and central assistance routed outside the state budget comprised 20-28 percent of the total public expenditure on health during 2005-07.

With regard to allocations by type of health care functions such as primary, secondary and tertiary, the findings indicate that the spending on secondary care (17 percent, on average) is abysmally low against 35 percent stated in the National Health Policy document. Even spending on primary care had not reached the prescribed limit of 55 percent in most of the years under study. With a substantially higher administrative expenditure, the state is constrained to allocate more resources to these heads. Again, low spending on primary and secondary care reflects wrong priority setting which affects equity issues in the health system.

Per capita health expenditure at current prices increased from Rs. 85 in 1996-97 to Rs. 206 in 2007-08 (BE). However, at constant prices, it was Rs. 95 in 2007-08. While it increased by almost 8 percent at current prices during the 12 -year study period, at constant prices it increased by only 3 percent. Findings, moreover, indicate that the state recorded one of the lowest per capita expenditures on health among the country's major states. With an average real per capita expenditure of Rs. 74 during 1991-92 to 2006-07, the state ranked eleventh among the major states. 
Although the maternal and child health situation in Orissa is characterised by considerable mortality and morbidity, health expenditure on maternal and child health is limited. For example, over the period 1996-97 to 2007-08, only 18 percent of health expenditure was on the provision of maternal and child health services. While expenditure on reproductive and child health services increased at a modest pace till 2004-05, it increased sharply thereafter, an increase that can be attributed largely to the increase in allocations routed outside the state budget. Of the total expenditure on reproductive and child health services, a major share - between 12 to 13 percent—was allocated for rural family welfare services and centres. In contrast, urban family welfare services and facilities received only 2 percent or less of the total expenditure on reproductive and child health services, and maternal and child health services received just 2-7 percent. It is also notable that only 3 percent or less was allocated for training. Further, although increased donor funding for reproductive and child health brings more flexibility in funding based upon planning, it raises questions of programme sustainability after funding ceases.

Findings also suggest that the actual spending fell short of budget estimates every year, and this was largely due to low utilisation of plan expenditure, thereby questioning the absorbing capacity and efficiency of the executing agencies in planning and implementing different programmes.

Financial transparency and management practices have a major bearing on the efficiency of public spending. Certain procurement related practices need to be changed to bring in greater transparency and involvement of technical experts. Age-old practices of drug procurement result in the supply of poor quality drugs and often, in their untimely supply, leading to poor results. This urgently calls for the introduction of reforms to enhance the effectiveness of public spending. Most of the earlier reform efforts were donor driven and introduced as a part of programme implementation strategies and could not be sustained.

Major policy issues such as the transfer of power to panchayati raj institutions and those involving health administration and management, human resource related subjects, particularly promotion and transfer policies and leadership issues, have adversely affected service delivery in the state. Concerted efforts need to be initiated in these areas in order to better planning, monitoring and utilisation of funds so as to improve maternal and child health services in Orissa. 


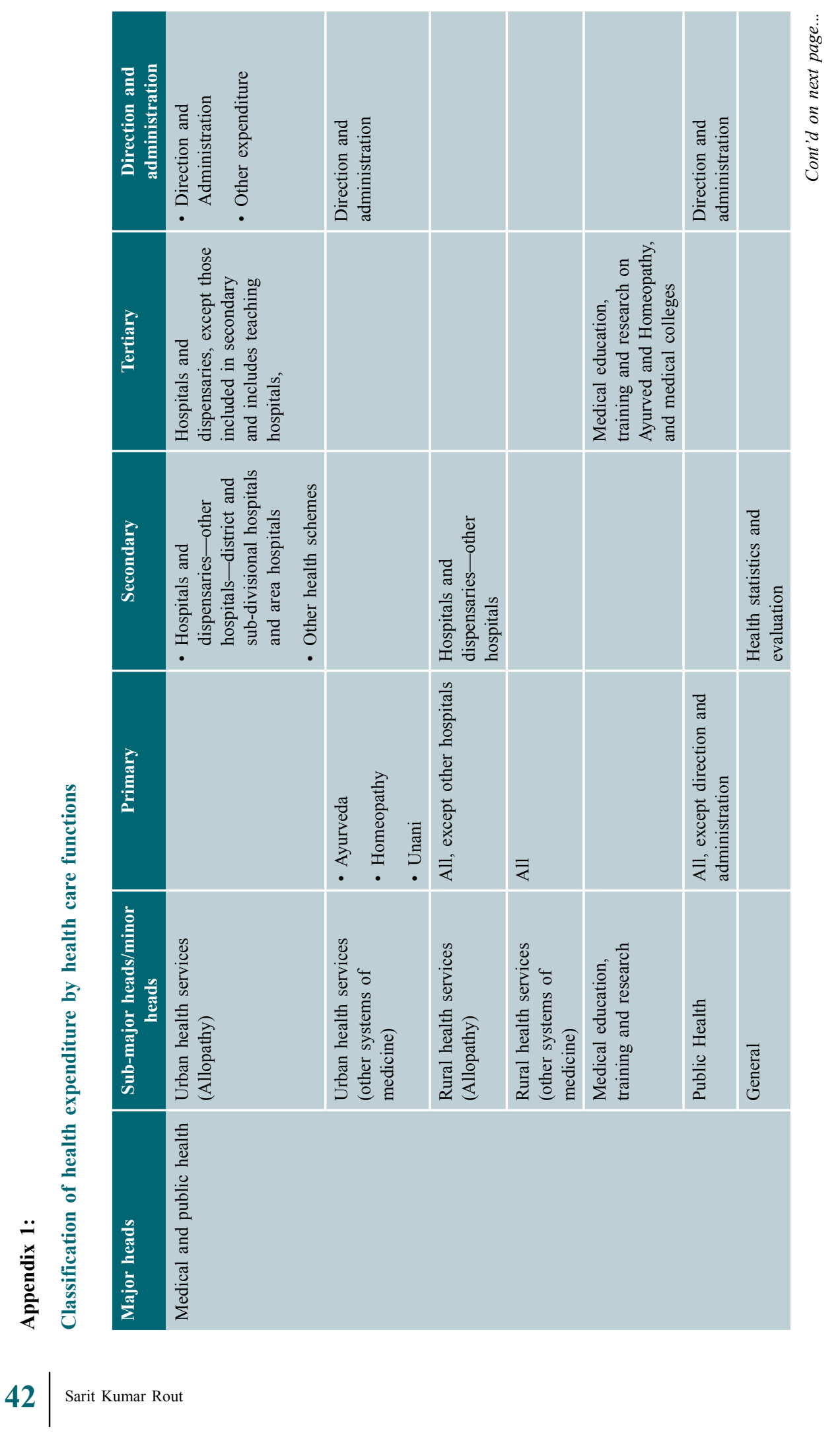




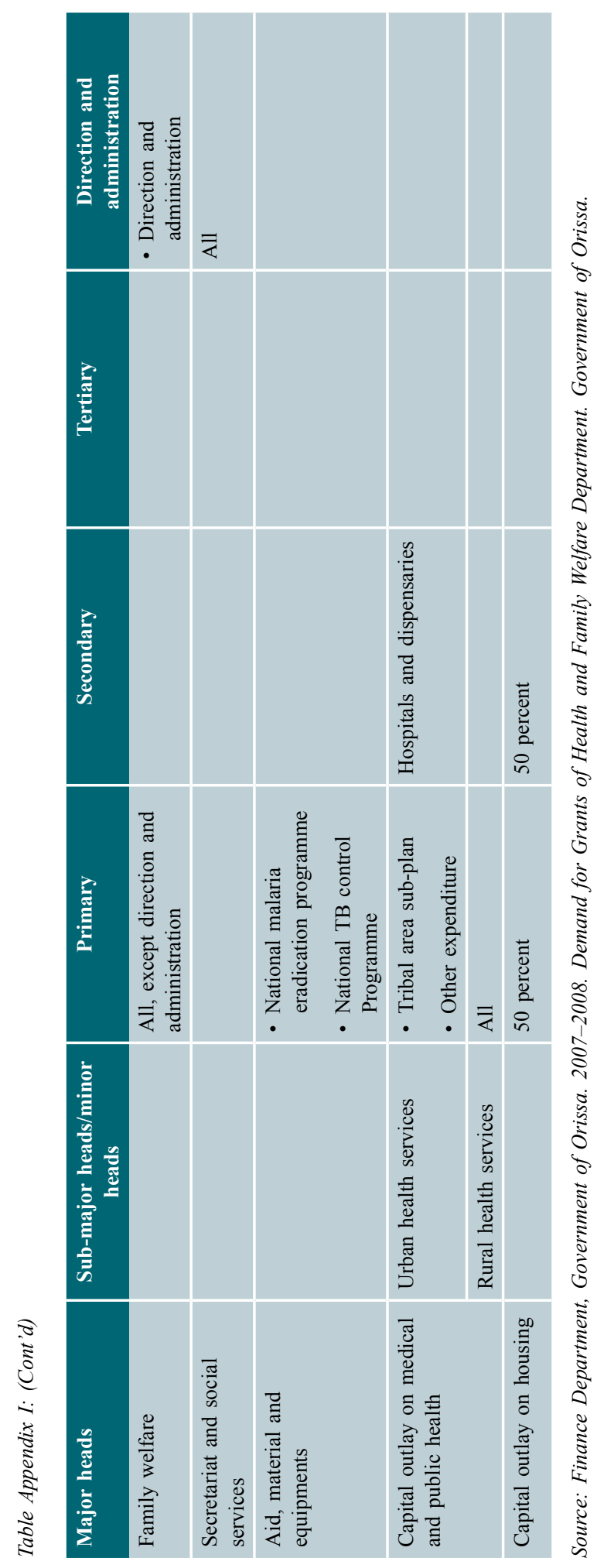

43 Public Expenditure on Health Care in Orissa: Focus on Reproductive and Child Health Services 


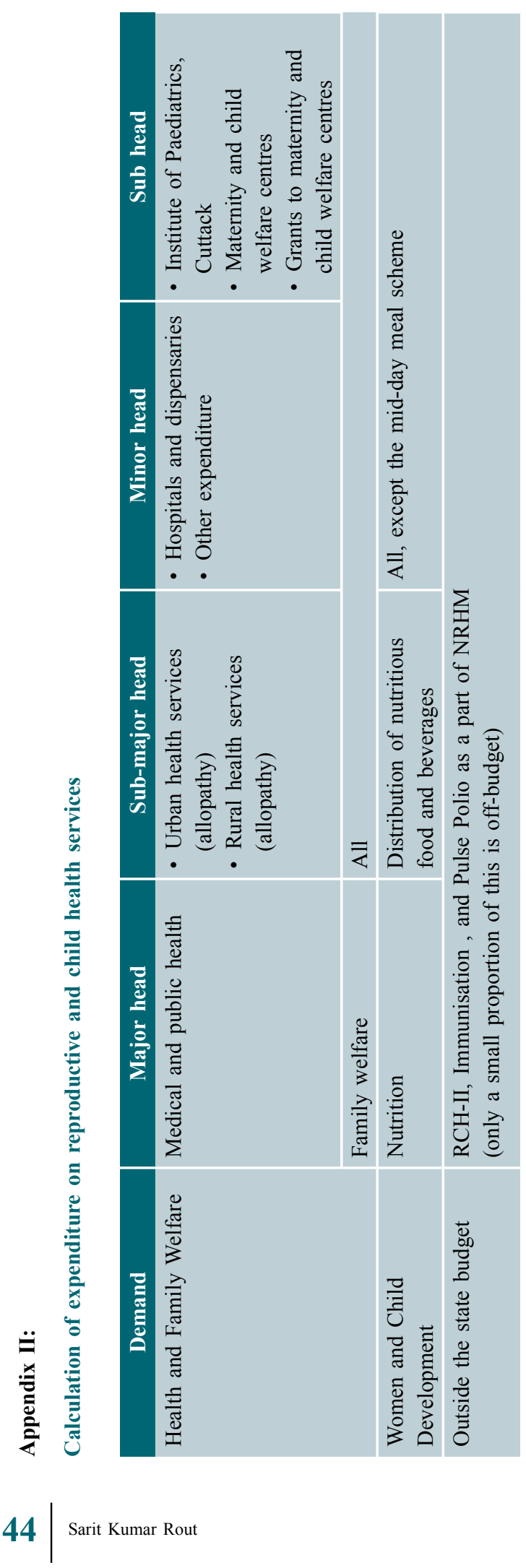


Annexure Tables

Table 1.1 A:

Major head wise classification of health-related expenditure, Orissa, 1996-97 to 2007-08 (in Rs. crore)

\begin{tabular}{|c|c|c|c|c|c|}
\hline \multirow[t]{2}{*}{ Year } & \multicolumn{3}{|c|}{ Water supply and sanitation } & \multirow{2}{*}{$\frac{\text { Nutrition }}{\text { Revenue }}$} & \multirow{2}{*}{$\begin{array}{r}\text { Grand } \\
\text { Total }\end{array}$} \\
\hline & Revenue & Capital & Total & & \\
\hline $1996-97$ & $\begin{array}{l}112.01 \\
(74.86)\end{array}$ & $\begin{array}{r}37.61 \\
(25.14)\end{array}$ & $\begin{array}{r}149.62 \\
(100.00)\end{array}$ & 94.09 & 243.71 \\
\hline $1997-98$ & $\begin{array}{l}146.17 \\
(76.80)\end{array}$ & $\begin{array}{r}44.15 \\
(23.20)\end{array}$ & $\begin{array}{r}190.32 \\
(100.00)\end{array}$ & 68.83 & 259.15 \\
\hline 1998-99 & $\begin{array}{l}218.70 \\
(85.70)\end{array}$ & $\begin{array}{r}36.49 \\
(14.30)\end{array}$ & $\begin{array}{r}255.19 \\
(100.00)\end{array}$ & 75.59 & 330.78 \\
\hline 1999-2000 & $\begin{array}{l}179.01 \\
(85.30)\end{array}$ & $\begin{array}{r}30.85 \\
(14.70)\end{array}$ & $\begin{array}{r}209.86 \\
(100.00)\end{array}$ & 68.40 & 278.26 \\
\hline $2000-01$ & $\begin{array}{l}166.63 \\
(75.24)\end{array}$ & $\begin{array}{r}54.82 \\
(24.76)\end{array}$ & $\begin{array}{r}221.45 \\
(100.00)\end{array}$ & 53.06 & 274.51 \\
\hline $2001-02$ & $\begin{array}{l}176.99 \\
(70.40)\end{array}$ & $\begin{array}{r}74.40 \\
(29.60)\end{array}$ & $\begin{array}{r}251.39 \\
(100.00)\end{array}$ & 46.58 & 297.97 \\
\hline $2002-03$ & $\begin{array}{l}203.53 \\
(81.85)\end{array}$ & $\begin{array}{r}45.14 \\
(18.15)\end{array}$ & $\begin{array}{r}248.67 \\
(100.00)\end{array}$ & 76.90 & 325.57 \\
\hline $2003-04$ & $\begin{array}{r}211.36 \\
(81.87)\end{array}$ & $\begin{array}{r}46.81 \\
(18.13)\end{array}$ & $\begin{array}{r}258.17 \\
(100.00)\end{array}$ & 61.59 & 319.76 \\
\hline $2004-05$ & $\begin{array}{l}228.64 \\
(82.99)\end{array}$ & $\begin{array}{r}46.86 \\
(17.01)\end{array}$ & $\begin{array}{r}275.50 \\
(100.00)\end{array}$ & 110.81 & 386.31 \\
\hline $2005-06$ & $\begin{array}{l}313.24 \\
(81.70)\end{array}$ & $\begin{array}{r}70.17 \\
(18.30)\end{array}$ & $\begin{array}{r}383.41 \\
(100.00)\end{array}$ & 230.58 & 613.99 \\
\hline 2006-07 (RE) & $\begin{array}{l}273.70 \\
(53.40)\end{array}$ & $\begin{array}{l}238.83 \\
(46.60)\end{array}$ & $\begin{array}{r}512.53 \\
(100.00)\end{array}$ & 306.47 & 819.00 \\
\hline 2007-08 (BE) & $\begin{array}{l}246.66 \\
(42.02)\end{array}$ & $\begin{array}{r}340.30 \\
(57.98)\end{array}$ & $\begin{array}{r}586.96 \\
(100.00)\end{array}$ & 198.65 & 785.61 \\
\hline
\end{tabular}

Note: Figure in parentheses indicates percentage of total expenditure.

Source: Finance Department, Government of Orissa. 1996-2008. Demand for Grants of Housing and Urban Development, Rural Development and Women and Child Development Departments. Government of Orissa. 
Table 1.2 A:

Sub-major head wise classification of health-related expenditure, Orissa, 1996-97 to 2007-08 (in Rs. crore)

\begin{tabular}{|c|c|c|c|c|}
\hline Year & $\begin{array}{l}\text { Water supply } \\
\text { and sanitation }\end{array}$ & $\begin{array}{c}\text { Sewerage and } \\
\text { sanitation }\end{array}$ & $\begin{array}{l}\text { Distribution of } \\
\text { Nutritious food } \\
\text { and beverages }\end{array}$ & Total \\
\hline 1996-97 & $\begin{array}{l}133.93 \\
(54.96)\end{array}$ & $\begin{array}{l}15.68 \\
(6.44)\end{array}$ & $\begin{array}{r}94.09 \\
(38.61)\end{array}$ & $\begin{array}{r}243.71 \\
(100.00)\end{array}$ \\
\hline 1997-98 & $\begin{array}{l}181.45 \\
(70.01)\end{array}$ & $\begin{array}{r}8.88 \\
(3.43)\end{array}$ & $\begin{array}{r}68.83 \\
(26.56)\end{array}$ & $\begin{array}{r}259.16 \\
(100.00)\end{array}$ \\
\hline 1998-99 & $\begin{array}{l}234.12 \\
(70.78)\end{array}$ & $\begin{array}{r}21.07 \\
(6.37)\end{array}$ & $\begin{array}{r}75.59 \\
(22.85)\end{array}$ & $\begin{array}{r}330.78 \\
(100.00)\end{array}$ \\
\hline 1999-2000 & $\begin{array}{l}198.10 \\
(71.19)\end{array}$ & $\begin{array}{r}11.76 \\
(4.23)\end{array}$ & $\begin{array}{r}68.40 \\
(24.58)\end{array}$ & $\begin{array}{r}278.26 \\
(100.00)\end{array}$ \\
\hline $2000-01$ & $\begin{array}{l}212.00 \\
(77.23)\end{array}$ & $\begin{array}{r}9.45 \\
(3.44)\end{array}$ & $\begin{array}{r}53.06 \\
(19.33)\end{array}$ & $\begin{array}{r}274.51 \\
(100.00)\end{array}$ \\
\hline $2001-02$ & $\begin{array}{l}245.00 \\
(82.22)\end{array}$ & $\begin{array}{r}6.39 \\
(2.14)\end{array}$ & $\begin{array}{r}46.58 \\
(15.63)\end{array}$ & $\begin{array}{r}297.97 \\
(100.00)\end{array}$ \\
\hline $2002-03$ & $\begin{array}{l}241.24 \\
(74.09)\end{array}$ & $\begin{array}{r}7.44 \\
(2.28)\end{array}$ & $\begin{array}{r}76.90 \\
(23.62)\end{array}$ & $\begin{array}{r}325.58 \\
(100.00)\end{array}$ \\
\hline 2003-04 & $\begin{array}{l}250.34 \\
(78.29)\end{array}$ & $\begin{array}{r}7.84 \\
(2.45)\end{array}$ & $\begin{array}{r}61.59 \\
(19.26)\end{array}$ & $\begin{array}{r}319.76 \\
(100.00)\end{array}$ \\
\hline 2004-05 & $\begin{array}{l}253.71 \\
(65.67)\end{array}$ & $\begin{array}{l}21.80 \\
(5.64)\end{array}$ & $\begin{array}{l}110.81 \\
(28.68)\end{array}$ & $\begin{array}{r}386.32 \\
(100.00)\end{array}$ \\
\hline $2005-06$ & $\begin{array}{r}356.68 \\
(58.09)\end{array}$ & $\begin{array}{r}26.73 \\
4.35\end{array}$ & $\begin{array}{r}230.58 \\
37.55\end{array}$ & $\begin{array}{l}613.99 \\
100.00\end{array}$ \\
\hline 2006-07 (BE) & $\begin{array}{l}420.02 \\
(56.11)\end{array}$ & $\begin{array}{r}84.60 \\
(11.30)\end{array}$ & $\begin{array}{l}243.99 \\
(32.59)\end{array}$ & $\begin{array}{r}748.62 \\
(100.00)\end{array}$ \\
\hline 2006-07 (RE) & $\begin{array}{l}448.13 \\
(54.72)\end{array}$ & $\begin{array}{r}64.40 \\
(7.86)\end{array}$ & $\begin{array}{l}306.47 \\
(37.42)\end{array}$ & $\begin{array}{r}819.01 \\
(100.00)\end{array}$ \\
\hline 2007-08 (BE) & $\begin{array}{l}452.76 \\
(57.63)\end{array}$ & $\begin{array}{r}134.20 \\
(17.08)\end{array}$ & $\begin{array}{l}198.65 \\
(25.29)\end{array}$ & $\begin{array}{r}785.61 \\
(100.00)\end{array}$ \\
\hline
\end{tabular}

Note: Figure in parentheses indicates percentage of total expenditure.

Source: Finance Department, Government of Orissa. 1996-2008. Demand for Grants of Housing and Urban Development, Rural Development and Women and Child Development Departments.

Government of Orissa. 
Table 1.3 A:

Plan and non plan distribution of health-related expenditure, Orissa, 1996-97 to 2007-08 (in Rs. crore)

\begin{tabular}{|c|c|c|c|c|c|c|}
\hline \multirow[t]{2}{*}{ Year } & \multicolumn{2}{|c|}{$\begin{array}{l}\text { Water supply and } \\
\text { sanitation }\end{array}$} & & \multicolumn{2}{|c|}{ Nutrition } & \multirow[t]{2}{*}{ Total } \\
\hline & Plan & Non Plan & Total & Plan & Non Plan & \\
\hline 1996-97 & $\begin{array}{r}112.15 \\
(74.96)\end{array}$ & $\begin{array}{r}37.47 \\
(25.04)\end{array}$ & $\begin{array}{r}149.62 \\
(100.00)\end{array}$ & $\begin{array}{r}79.32 \\
(84.31)\end{array}$ & $\begin{array}{r}14.77 \\
(15.69)\end{array}$ & $\begin{array}{r}94.09 \\
(100.00)\end{array}$ \\
\hline 1997-98 & $\begin{array}{r}148.08 \\
(77.80)\end{array}$ & $\begin{array}{r}42.25 \\
(22.20)\end{array}$ & $\begin{array}{r}190.33 \\
(100.00)\end{array}$ & $\begin{array}{r}55.74 \\
(80.98)\end{array}$ & $\begin{array}{r}13.09 \\
(19.02)\end{array}$ & $\begin{array}{r}68.83 \\
(100.00)\end{array}$ \\
\hline 1998-99 & $\begin{array}{l}155.55 \\
(60.95)\end{array}$ & $\begin{array}{r}99.64 \\
(39.05)\end{array}$ & $\begin{array}{r}255.19 \\
(100.00)\end{array}$ & $\begin{array}{r}62.10 \\
(82.15)\end{array}$ & $\begin{array}{r}13.49 \\
(17.85)\end{array}$ & $\begin{array}{r}75.59 \\
(100.00)\end{array}$ \\
\hline 1999-2000 & $\begin{array}{l}159.48 \\
(75.99)\end{array}$ & $\begin{array}{r}50.39 \\
(24.01)\end{array}$ & $\begin{array}{r}209.86 \\
(100.00)\end{array}$ & $\begin{array}{r}50.21 \\
(73.41)\end{array}$ & $\begin{array}{r}18.18 \\
(26.59)\end{array}$ & $\begin{array}{r}68.40 \\
(100.00)\end{array}$ \\
\hline $2000-01$ & $\begin{array}{l}145.22 \\
(65.58)\end{array}$ & $\begin{array}{r}76.23 \\
(34.42)\end{array}$ & $\begin{array}{r}221.45 \\
(100.00)\end{array}$ & $\begin{array}{r}44.10 \\
(83.11)\end{array}$ & $\begin{array}{r}8.96 \\
(16.89)\end{array}$ & $\begin{array}{r}53.06 \\
(100.00)\end{array}$ \\
\hline $2001-02$ & $\begin{array}{l}164.89 \\
(65.59)\end{array}$ & $\begin{array}{r}86.49 \\
(34.41)\end{array}$ & $\begin{array}{r}251.39 \\
(100.00)\end{array}$ & $\begin{array}{r}38.39 \\
(82.42)\end{array}$ & $\begin{array}{r}8.19 \\
(17.58)\end{array}$ & $\begin{array}{r}46.58 \\
(100.00)\end{array}$ \\
\hline $2002-03$ & $\begin{array}{l}152.74 \\
(61.42)\end{array}$ & $\begin{array}{r}95.94 \\
(38.58)\end{array}$ & $\begin{array}{r}248.67 \\
(100.00)\end{array}$ & $\begin{array}{r}69.79 \\
(90.74)\end{array}$ & $\begin{array}{r}7.12 \\
(9.26)\end{array}$ & $\begin{array}{r}76.90 \\
(100.00)\end{array}$ \\
\hline 2003-04 & $\begin{array}{r}153.21 \\
(59.34)\end{array}$ & $\begin{array}{r}104.97 \\
(40.66)\end{array}$ & $\begin{array}{r}258.17 \\
(100.00)\end{array}$ & $\begin{array}{r}56.95 \\
(92.46)\end{array}$ & $\begin{array}{r}4.64 \\
(7.54)\end{array}$ & $\begin{array}{r}61.59 \\
(100.00)\end{array}$ \\
\hline 2004-05 & $\begin{array}{l}158.31 \\
(57.46)\end{array}$ & $\begin{array}{r}117.19 \\
(42.54)\end{array}$ & $\begin{array}{r}275.50 \\
(100.00)\end{array}$ & $\begin{array}{l}104.69 \\
(94.47)\end{array}$ & $\begin{array}{r}6.12 \\
(5.53)\end{array}$ & $\begin{array}{r}110.81 \\
(100.00)\end{array}$ \\
\hline 2005-06 & $\begin{array}{l}258.44 \\
(67.40)\end{array}$ & $\begin{array}{l}124.98 \\
(32.60)\end{array}$ & $\begin{array}{r}383.41 \\
(100.00)\end{array}$ & $\begin{array}{l}223.98 \\
(97.14)\end{array}$ & $\begin{array}{r}6.60 \\
(2.86)\end{array}$ & $\begin{array}{r}230.58 \\
(100.00)\end{array}$ \\
\hline 2006-07 (RE) & $\begin{array}{l}392.53 \\
(76.59)\end{array}$ & $\begin{array}{l}120.01 \\
(23.41)\end{array}$ & $\begin{array}{r}512.54 \\
(100.00)\end{array}$ & $\begin{array}{l}305.15 \\
(99.57)\end{array}$ & $\begin{array}{r}1.32 \\
(0.43)\end{array}$ & $\begin{array}{r}306.47 \\
(100.00)\end{array}$ \\
\hline 2007-08 (BE) & $\begin{array}{l}468.59 \\
(79.83)\end{array}$ & $\begin{array}{l}118.37 \\
(20.17)\end{array}$ & $\begin{array}{r}586.96 \\
(100.00)\end{array}$ & $\begin{array}{l}197.18 \\
(99.26)\end{array}$ & $\begin{array}{r}1.48 \\
(0.74)\end{array}$ & $\begin{array}{r}198.65 \\
(100.00)\end{array}$ \\
\hline
\end{tabular}

Note: Figure in parentheses indicates percentage of total expenditure.

Source: Finance Department, Government of Orissa. 1996-2008. Demand for Grants of Housing and Urban Development, Rural Development and, Women and Child Development Departments. Government of Orissa. 


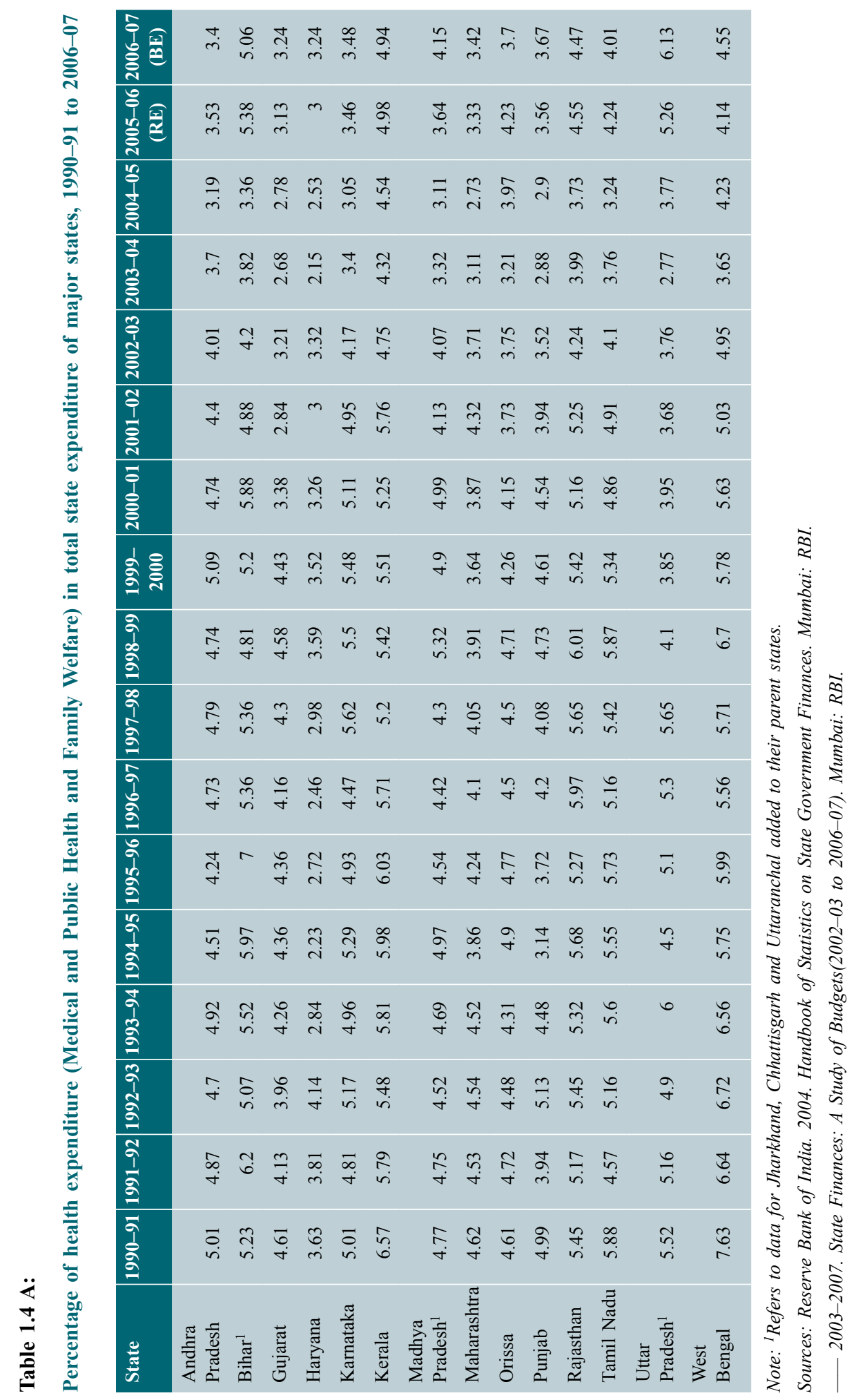

48 Sarit Kumar Rout 


\section{Acknowledgements}

This working paper is the outcome of the Health Population and Innovation Fellowship (HPIF) programme awarded to the author during 2006-07. I would like to provide my sincere thanks to various stakeholders, including the Departments of Health and Family Welfare and Finance, Government of Orissa, the State Institute of Health and Family Welfare, and the research wing of the Centre for Youth and Social Development (CYSD), Bhubaneswar, for facilitating access to data. My sincere thanks are due to Mr. Panchanan Kanungo, Ex-finance minister, Government of Orissa, Mr. Vidyasagar Pattanaik, Research Officer, Reserve Bank of India, Mumbai, Dr. Bhagabata Patro, Professor of Economics, Berhampur University, and Late Dr. Shakti Padhi, Professor of Economics, Nabakrushna Choudhary Center for Development Studies (NCDS), Bhubaneswar, for providing valuable inputs into the report. I also sincerely acknowledge the inputs received from experts who participated in the state level workshop held in Bhubaneswar, and in the regional workshop held at Berhampur University, in collaboration with its Department of Economics. My special thanks are due to Dr. Barun Knajilal, Professor of Economics, Indian Institute of Health Management and Research (IIHMR), Jaipur, Rajasthan and Mr. Ravi Duggal, Independent Consultant/Researcher for providing valuable insights during the finalisation of the report. While preparing the report, I consulted many libraries including those at IIHMR, Jaipur, the National Institute of Public Finance and Policy (NIPFP), New Delhi, and the Nabakrushna Choudhary Centre for Development Studies (NCDS), Bhubaneswar, and I would like to thank the staff of these libraries for their support in providing documents and reports. I would also like to thank Mr. Milan Sahoo, research associate of the project, who worked sincerely, was responsible for collecting data and helped me during preparation of the report.

I would like to thank Shireen Jejeebhoy, Shveta Kalyanwala, K.G. Santhya and Komal Saxena at the Population Council for their continued guidance during the project and for providing inputs in previous versions of this paper. I am grateful to Jyoti Moodbidri for editing the manuscript.

Last but not least I express my sincere gratitude to my parents and wife for their constant support and encouragement throughout the study. 


\section{References}

Berman, Peter. 1991. Health Economics, Health Financing and Health Needs of Poor Women in India. The Ford Foundation: New Delhi.

. 1996. National Health Accounts in Developing Countries: Appropriate Methods and Recent Applications, Data Decision Making Project. Harvard School of Public Health: Boston, USA.

Comptroller and Auditor General of India. 2006. Appropriation Accounts 2005-06. Government of Orissa.

Directorate of Economics and Statistics, Government of Orissa. 2005-06 to 2008-09. Economic Survey. Planning and Coordination Department, Government of Orissa.

Finance Department, Government of Orissa. 1996-2008. Demand for Grants of Health and Family Welfare Housing and Urban Development, Rural Development, Labour and Employment and Women and Child Development Departments. Government of Orissa.

—. 2003-2004. Budget At A Glance. Government of Orissa.

- 2004-2008. Budget At A Glance. Government of Orissa.

—. 2007. Explanatory Memorandum (Budget 2007-2008). Government of Orissa.

Health and Family Welfare Department. 2002. Orissa State Integrated Health Policy-2002. Government of Orissa.

—. 2003. Orissa Vision 2010 - A Health Strategy. Government of Orissa.

International Institute for Population Sciences (IIPS). 2007-08. DLHS 3 Fact Sheet, Orissa. Mumbai: IIPS.

International Institute for Population Sciences (IIPS) and Macro International. 2008. National Family Health Survey (NFHS-3), India, 2005-06: Orissa. Mumbai: IIPS.

Indira, A. and V. Vyasulu. 2001. The Health budget in Karnataka. Centre for Budget and Policy Studies (CBPS): Bangalore.

Ministry of Health and Family Welfare (MOHFW). 2005. National Health Accounts India 2001-02. New Delhi: MOHFW, Government of India.

2007. Select Health Parameters: A Comparative Analysis across National Sample Survey Organization (NSSO) $42^{\text {nd }}, 52^{\text {nd }}$ and $60^{\text {th }}$ Rounds. New Delhi: MOHFW, Government of India. 
. 2009. National Health Accounts India 2004-05 with provisional estimates from 2005-06 to 2008-09. New Delhi: MOHFW, Government of India.

National Sample Survey Organization (NSSO). 2006. Morbidity, Health care and conditioned of the aged, NSS $60^{\text {th }}$ Round, January-June, 2004. Ministry of Statistics and Programme Implementation, Government of India.

Rao, N. B., M. E. Khan and C.V.S Prasad. 1987. Health Sector Expenditure Differentials in India. Baroda: ORG.

Reddy, K.N. and V Selvaraju. 1994. Health Expenditure by Governments in India: 1974-75 to 1990-91. New Delhi: National Institute of Public Finance and Policy.

Office of the Registrar General and Census Commissioner. 2001. Primary Census Abstract, Total Population: Table A-5, Series 1. New Delhi: Office of the Registrar General and Census Commissioner.

Office of the Registrar General, India. 2009a. SRS Bulletin: Sample Registration System, 43(1). New Delhi: RGI.

. 2009b. Special Bulletin on Maternal Mortality in India 2004-06. New Delhi: RGI.

Reserve Bank of India (RBI). 2004. Handbook of Statistics on State Government Finances. Mumbai: RBI.

RBI. . 2003-2007. State Finances: A Study of Budgets (2002-03 to 2006-07). Mumbai: 


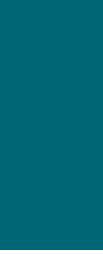


53 Public Expenditure on Health Care in Orissa: Focus on Reproductive and Child Health Services 


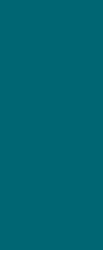



